\title{
Foreign institutional ownership and demand for accounting conservatism: evidence from an emerging market
}

\author{
Mohamed Khalil ${ }^{1,2}$ (D) Aydin Ozkanc ${ }^{3} \cdot$ Yilmaz Yildiz $^{3}$
}

Published online: 10 September 2019

(c) The Author(s) 2019

\begin{abstract}
This study investigates how foreign institutional ownership interacts with accounting conservatism in an emerging market setting. We posit that weak investor protection and a high degree of information asymmetry between insiders and outside investors increase demand for conservative reporting in firms operating in emerging markets. Foreign investors in this setting have informational disadvantages relative to their domestic peers and have difficulties in getting access to data. Using a sample of Turkish firms, we find that foreign institutions (particularly foreign corporate investors) demand more conservative reporting in the investee firms. Moreover, we show that this association is more pronounced among firms with greater asymmetric information problems and growth opportunities. Our additional tests reveal that the direction of causality flows from foreign institutional ownership to conservatism, and not vice versa.
\end{abstract}

Keywords Accounting conservatism · Foreign ownership · Institutional investors · Emerging market

JEL classification M41 - G2 - G34

\section{Introduction}

The liberalization of capital markets and the integrated global economy have made foreign capital an important source of financing for corporations. Understanding the impact of foreign ownership on determining corporate policies has hence gained significant interest.

Aydin Ozkanc

a.ozkan@hud.ac.uk

Mohamed Khalil

m.khalil@hull.ac.uk

Yilmaz Yildiz

y.yildiz@hud.ac.uk

1 Hull University Business School, University of Hull, Hull, UK

2 Faculty of Commerce, Tanta University, Tanta, Egypt

3 Huddersfield Business School, University of Huddersfield, Huddersfield, UK 
Recent research shows that foreign ownership in domestic companies is associated with better corporate governance structure (Aggarwal et al. 2011; Desender et al. 2016; Kim et al. 2016); higher firm value and performance (Ferreira and Matos 2008); high-quality auditor choice (He et al. 2014); and more long-term investment in assets and human capital (Bena et al. 2017).

Despite ample research on the factors that attract foreign investors, relatively little is known about the influence that foreign investors can exert in promoting conservative reporting. This paper seeks to fill this gap by empirically investigating the influence exerted by foreign institutional ownership on the extent of firm-level conservative accounting. The main motivation emanates from the generally accepted view that foreign investors have an informational disadvantage relative to their domestic peers (Ferreira et al. 2017). In addition to the difficulties in getting access to data, foreign investors are also disadvantaged in interpreting the financial statements of domestic corporations (Beneish and Yohn 2008). In support of this view, it is shown that foreign investors have stronger incentives to monitor the local firms in which they have equity ownership and impact their policies and governance structure (Desender et al. 2016; Sakaki et al. 2017).

The main research question in this paper is whether foreign institutional investors demand a higher level of conservative reporting in domestic investee firms. We argue that foreign institutional investors desire greater conservatism, and hence, expect a positive relation between the level of their ownership and the degree of accounting conservatism. In predicting this relationship, we rely on two premises. First, the high verifiability of difficult-to-verify information characteristic of conservative reporting can help mitigate the degree of information asymmetry between insiders and foreign investors by accelerating loss recognition. Second, conservative reporting can alleviate the costly agency incentives of corporate managers because it can act as a governance device to compensate for weak investor protection and poor corporate governance in a setting where the conflicts between controlling and outside shareholders are expected to be severe.

In this study, we examine the relation between foreign institutional ownership and accounting conservatism using data from an emerging market. In this respect, Turkey constitutes an ideal setting. Emerging countries are typically characterized by loose institutional arrangements and inadequate protection of investors. Therefore, the potential agency and informational benefits of conservative accounting are expected to be more appealing to outside investors (Hu and Jiang 2019). Furthermore, a hybrid corporate governance system of Turkey, which combines the characteristics of the market-based and relationship-based systems, may translate into inferior, not necessarily stronger, rights for stakeholders (Ciftci et al. 2019). This, in turn, makes the investigation of the role of conservative reporting in reducing the tension between insiders and outside investors more relevant. Also, Turkey is a Muslim-majority European Union (EU) candidate with a diverse and sophisticated institutional setting, which has been shaped over the centuries through political and economic interactions with the western and eastern civilizations. In this respect, it is likely to play a leading role in terms of the development in financial markets, corporate governance and accounting practices. Consequently, the findings of this study may be relevant not only for Turkey but also for other countries that can associate themselves more easily with Turkey.

The measurement of the degree of conservative reporting is challenging. We employ Basu's (1997) asymmetric timeliness of earnings as the primary measure of accounting conservatism. We also use the transitory gain and loss components suggested by Ball and Shivakumar (2005) as an alternative measure. In carrying out our regression analysis, we use a large dataset of 1618 firm-year observations drawn from non-financial publicly listed companies in Turkey over the period 2007-2015. As for the measure of institutional 
ownership, following Ramalingegowda and Yu (2012), we utilize a measure of residual rather than raw ownership to overcome the endogeneity of institutional ownership.

Consistent with our predictions, we find evidence that higher levels of foreign institutional ownership are associated with greater accounting conservatism. Also, this result is mainly driven by the behavior of corporate investors who have longer investment horizons and greater monitoring power. The findings reveal that the influence exerted by foreign institutional ownership is more significant in firms with greater information asymmetry and growth opportunities. The results are robust to different measures of accounting conservatism. Overall, our findings are consistent with the view that foreign institutional investors improve investee firms' financial reporting quality by demanding more conservative reporting and the demand is stronger when direct monitoring is difficult. Although our results indicate a positive relation between foreign institutional ownership and accounting conservatism, it is possible that conservative reporting is chosen by domestic firms to attract foreign investors. To mitigate this potential reverse causality, we also estimate empirical specifications using the lead and lag values of accounting conservatism and foreign institutional investment. The results of this analysis suggest that the causality runs from residual foreign institutional holdings to accounting conservatism.

Our study complements prior studies on the governance role of accounting conservatism and adds to the strand of the literature that investigates the governance role of foreign investors (e.g., Beekes et al. 2004; Bushman et al. 2004; Ahmed and Duellman 2007; Lafond and Roychowdhury 2008; García Lara et al. 2009). Although several studies examine the relation between institutional ownership and conservatism, to our knowledge, this is the first study that investigates the impact of foreign institutional ownership on accounting conservatism. The closely related prior work is Beuselinck et al. (2017), which find that increases in foreign ownership lead to better financial reporting when the investor is domiciled in a strong investor protection country. Our analysis complements this work by examining the demand for accounting conservatism by foreign institutional investors within a unique setting where the protection of investors is relatively weak. Accounting conservatism thus provides a potential channel through which foreign institutional investors can extract sufficient information and reduce potential agency conflicts.

The remainder of the paper proceeds as follows. Section 2 provides a brief discussion of the institutional setting in Turkey. Section 3 develops hypotheses. Section 4 describes the data, empirical proxies and specifications. Section 5 presents the results while Sect. 6 provides additional tests. Section 7 concludes the paper.

\section{Institutional setting}

The role of accounting is shaped by the institutional setting in which they take place. We, therefore, in the following give a brief historical perspective which constitutes a useful background to the scope of our study. The first financial modernization step in Ottoman Empire was taken in 1839 with the "Tanzimat" edict, which also led to the establishment of today's Ministry of Finance. The Turkish accounting system was initially influenced by the French system, and the first accounting regulation of Turkey was the translation of the French Commercial Code in 1850. However, the French influence weakened after the establishment of modern Turkey in 1923. The second commercial code was enacted in 1926 with a strong influence of Germany due to close political connections until World War I (Simga-Mugan 1995). Although the influence of the French and German systems is 
still relatively apparent since the 1950s, the Turkish accounting regime has been influenced by the USA accounting system (Elitas and Uc 2009).

With the establishment of the Istanbul Stock Exchange (ISE) (former name of Borsa Istanbul) in 1986, Turkey adopted the first set of accounting standards, and all publicly listed firms were obligated to follow these standards. Among other regulators in charge of the enforcement of accounting standards, the Capital Markets Board (CMB), which is established by The Capital Markets Law of 1981, is responsible for determining and monitoring the compliance with the accounting and auditing requirements governing the financial information. The current commercial code, which came into effect in 2012, empowers the Turkish Accounting Standards Board (TASB) as the sole authority to set the Turkish Accounting Standards (TAS). All companies other than small and medium-sized entities (SMEs) are required to prepare their consolidated financial statements following the TAS, which are generally based on the International Financial Reporting Standards (IFRS). The current Commercial Code also requires the audit of financial statements of publicly-held companies to be made according to the Turkish Auditing Standards, which are in line with the International Standards of Auditing, by independent auditors. ${ }^{1}$

Aiming to improve the quality of financial reporting and facilitating better access to international funds, from January 2005, the CMB permitted the full adoption of IFRS for the financial periods ended December 31, 2003, onwards (World Bank 2007). However, some dissimilarities between the TAS and IFRS still exist in practice (World Bank 2007). ${ }^{2}$ It is worth pointing out that the Revenues Administration within the Ministry of Finance also mandates accounting requirements that need to be followed by all entities to meet the needs of tax collection. These tax-based requirements, however, do not necessarily satisfy the informational needs of several users, such as international investors, which use general purpose financial statements for investment decisions.

Finally, foreign investors, according to the Foreign Direct Investment Law No 4875, issued in 2003, are free to make investments and transfer profits, dividends, and any other proceeds from sales of investment abroad. It is worth noting that listed firms in Turkey are subject to the authority of several agencies with overlapping and ambiguous laws, which weakens law enforcement and reduces the litigation risk. Although the Turkish civil law is broadly influenced by the Anglo-Saxon system, it is a hybrid-based system that is not shareholder rights orientated. For example, although the Borsa Istanbul has appropriate sanctions and actions, including the requirement to publish information omitted from the financial statements, correction of the financial statements, fines, and prohibition of trading (World Bank 2007), sanctions are relatively mild and often not applied in practice.

\footnotetext{
1 The commercial code, Temporary Article 2, mentions: "Until a Turkish Auditing Standards Board with a judicial personality is established, the Turkish Auditing Standards, mentioned in Article 397, are determined by a board affiliated to the Union of Certified Public Accountants of Turkey (TÜRMOB) in harmony with ISA. A regulation, regarding which institutions and organisations' representatives will constitute the board and its work principles and procedures, will be prepared by TÜRMOB and published upon the approval of the Ministry of Finance."

${ }^{2}$ For a discussion of these differences and non-compliance issues, see the Report on the Observance of Standards and Codes (World Bank 2007: 24-28) on accounting and auditing in Turkey issued in 2007. The report is available at http://documents.worldbank.org/curated/en/974031468172442987/pdf/662380ROSC 00PU04B0Turkey0March02007.pdf [accessed 30 December 2018]. .
} 


\section{Hypotheses development}

Basu (1997) defines conservatism as the tendency of accountants to require a higher degree of verification for recognizing good news than bad news in financial statements. It is measured as reflecting bad news more quickly than good news in earnings. According to the contractual explanation of conservatism, it mitigates the agency problems within firms through offsetting the opportunistic behavior of managers and reducing their incentives to manipulate earnings (Watts 2003). Given that economic losses are reported more quickly than economic gains under a conservative reporting regime, conservatism is expected to reduce the ability of managers to overstate earnings and net assets. Equity investors, therefore, are likely to demand conservative reporting to mitigate their informational disadvantage position compared to insiders and eliminate any undesirable consequences of information asymmetries. In a similar reasoning, conservative reporting disciplines managers concerning risky investment decisions since their compensation is directly related to firm performance (Ball 2001).

Previous literature provides supporting evidence that equity investors are an important source of demand for conservative reporting. LaFond and Watts (2008) find that accounting conservatism is a response to the information asymmetries present within firms. Thus, an increase in the extent of asymmetric information between insiders and outsiders should lead to greater conservatism. In a similar vein, LaFond and Roychowdhury (2008) provide additional evidence on the relationship between agency costs and accounting conservatism focusing on the effects of managerial ownership on accounting conservatism. Their findings show that the demand for conservative financial reporting increases at lower levels of managerial ownership when the agency conflicts and costs are expected to be greater.

It is worth noting that foreign institutional investors are subject to greater agency problems and ex-ante information asymmetry. Given the information gap between local and foreign investors as well as inferior legal protection and law enforcement, the managers of firms with concentrated ownership may have incentives to limit access to information by outside investors (Fan and Wong 2002). Kim and Zhang (2016) find a negative association between the degree of conditional conservatism and the likelihood of a firm experiencing future stock price crashes and this association is more pronounced in an environment where the extent of information asymmetries is more pronounced. This limited information transparency, however, may be compensated by higher demand for more conservative reporting by outside investors (Wang 2006).

Earlier studies provide evidence that foreign institutional investors play a crucial role in improving the corporate governance quality of firms. It is shown that changes in the holdings of foreign institutional ownership lead to subsequent changes in corporate governance practices (Gillan and Starks 2003; Aggarwal et al. 2011; Desender et al. 2016) and improved voluntary corporate disclosure (Liang et al. 2012). In Taiwan, Liang et al. (2012) find a positive association between the likelihood and the frequency of holding conference calls and foreign institutional ownership. Additionally, Ramalingegowda and Yu (2012) show that the primary demand for conservative reporting arises from monitoring institutional investors rather than short-term non-monitoring institutional investors. Specifically, they find that an increase in the ownership of monitoring institutional investors is positively associated with greater demand on accounting conservatism since these investors have longer investment horizons, which make them enjoy the benefits of conservative reporting. Similarly, Lin (2016) provides supporting evidence on the positive relationship between dedicated institutional ownership and conservative reporting. 
In a related study, Cheng et al. (2015) show that hedge fund activists are positively associated with higher accounting conservatism from target firms when hedge funds have relatively high ownership and hold their investment for at least 1 year. They also find more conservative reporting when the pre-intervention of dedicated institutional investors is low, suggesting a substitution intervention between hedge funds and dedicated institutional investors to impose higher conservative reporting in target firms.

Bushman et al. (2004) demonstrate that the low timeliness of financial reporting increases the demand for costly corporate governance mechanisms that help to alleviate moral hazard problems. They find an inverse relation between the strength of corporate governance and earnings timeliness for a sample of firms in the Fortune 1000. They conclude that strong corporate governance systems act as a substitute for the low timeliness of accounting information. In a similar vein, Wang (2006) examine the association between founding family ownership and the quality of financial reporting for a sample of firms listed on the Standard and Poor's 500 during the period 1994-2002. He finds that family ownership is positively associated with higher earnings quality consistent with the view that the interests of founding families are better aligned with those of other investors, or the association perhaps resulted from greater demand for higher earnings quality by investors. This result is in line with Chen et al. (2014) who find that accounting conservatism increases with non-CEO family ownership and that this positive relation is weaker in family firms with a founder CEO. Conversely, Basu et al. (2005) show, using a sample of Taiwanese firms during the period 1991-1996, that family-owned firms exhibit lower earnings conservatism. However, Eng and Lin (2012) find that Chinese firms cross-listed in Hong Kong and the US do not show lesser earnings management practice or higher earnings quality. In similar vien, Lai and Tam (2017) find no association between foreign ownership and earnings manipulation in China.

There are several reasons for effective monitoring by foreign institutional investors. First, compared to domestic investors, foreign investors are more experienced in international markets, which make them more aware and informed about the value of improved financial reporting quality and better corporate governance practices (Aggarwal et al. 2011; Beuselinck et al. 2017). Second, foreign institutional investors can process valuerelevant information more quickly and effectively due to their technological advantage (Grinblatt and Keloharju 2000). Third, foreign institutions can impose conservative financial reporting directly by voicing their dissatisfaction over the low-quality information, or indirectly by selling their shares ('vote with their feet') (Gillan and Starks 2003; Ferreira and Matos 2008; Aggarwal et al. 2011). They are also less hindered by close relations and direct business ties with local controlling insiders. Finally, as a result of the local and global regulations, institutional investors are considered the guardians of corporate governance, which also encourages them to be more active than domestic investors in adopting better governance practices within the firm (Kim et al. 2016). Consistent with these views, Kim et al. (2016) and Lel (2017), using cross-country data, investigate the role of foreign institutional investors in constraining earnings management activities and find that firms with higher foreign ownership engage less in earnings manipulation.

The above arguments lead to the following hypothesis:

$\mathbf{H}_{\mathbf{1}}$ Foreign institutional ownership is positively associated with financial reporting conservatism. 
We argue that foreign institutional investors with different motives and investment strategies also differ in the extent of their demand for conservative reporting. The agency theory suggests that foreign corporations play more effective monitoring role due to their concentrated and larger ownership in domestic firms (Douma et al. 2006). They also tend to have a longer investment horizon, and hence, they are more able to reap the long-term benefits of conservative reporting. Conversely, foreign financial institutions are more interested in short-term profits since the performance of fund managers is assessed over relatively shorter durations. Moreover, funds hold smaller and fragmented shares in firms to enjoy the benefits of diversification (Douma et al. 2006). Furthermore, fund managers tend to change their portfolio holdings when they are unable to maintain short-term gains, making them less sensitive to the changes in corporate reporting practices. Likewise, prior evidence suggests that institutions with greater concentrated and strategic ownership are more likely to monitor the management (Chen et al. 2007). Consistent with this view, Ramalingegowda and Yu (2012) find a positive relationship between the shareholdings of monitoring institutions and conservative reporting. In a similar vein, Lin and Manowan (2012) find a positive relationship between ownership by non-monitoring institutional investors (i.e., transient) and earnings management. Therefore, it is reasonable to expect that foreign corporate investors are more likely to have the incentives and ability to enforce higher conservatism in financial reporting than foreign funds.

Based on the above discussion, we formulate the second hypothesis as follows:

$\mathbf{H}_{\mathbf{2}}$ Foreign corporate ownership is more positively associated with financial reporting conservatism than foreign funds ownership.

Furthermore, the governance-related characteristics of firms may also exert a considerable impact on the relationship between foreign institutional ownership and accounting conservatism. Since it is more difficult to monitor the managers of high-growth firms and firms that are prone to higher information asymmetry, the marginal value of monitoring and the demand for conservatism in such firms are greater (Smith and Watts 1992; Ramalingegowda and Yu 2012). In support of this argument, Lel (2017) and Kim et al. (2016) find that the monitoring effectiveness of foreign investors is more apparent in firms with higher agency conflicts and information asymmetries. Kim et al. (2016) also suggest that the monitoring effectiveness of global investors is greater in firms with weaker corporate governance mechanisms. As argued earlier, foreign investors face informational disadvantages relative to domestic investors, which is at the core of foreign investors' investment decisions. Given the difficulty of direct monitoring in these firms, conservative reporting can be desired as an additional governance mechanism that can discipline the manager's reporting incentives. Therefore, it is reasonable to expect a stronger relationship between accounting conservatism and the monitoring ownership in firms with greater information asymmetry and growth options. The above discussion leads to the following hypothesis:

$\mathbf{H}_{\mathbf{3}}$ The positive association between foreign institutional ownership and conservative reporting is more pronounced for firms with greater information asymmetries and growth options. 


\section{Data and methodology}

We obtain the foreign and domestic ownership data from the Central Securities Depository Institution of Turkey, which has the authority to issue capital market instruments, register the instruments into accounts and keep the records of accounts at the highest level. ${ }^{3}$ This database provides fiscal year-end information about the type of equity ownership such as domestic/foreign individuals, investment funds and corporate (corporations and limited liability companies) investors. The raw ownership data for each ownership category are handcollected from annual reports that are obtained from the Central Depository Institution of Turkey. We obtain other firm-specific accounting and market data from Datastream. We exclude the financial firms in the sample as they are subject to unique disclosure requirements, regulation measurement, and external scrutiny. We also drop firms with missing ownership and incomplete accounting data required to conduct the empirical analysis. Our final sample consists of 1618 firm-years from 2007 to 2015.

\subsection{Measurement of residual ownership}

Previous evidence on the relationship between conservatism and ownership structure suggests that many of the firm-specific characteristics are endogenously determined (Ramalingegowda and Yu 2012). Such endogeneity arises because firm-specific characteristics, such as size and market-to-book ratio, are likely to have an impact on both conservatism and ownership. Therefore, following prior research (e.g., LaFond and Roychowdhury 2008; Ramalingegowda and Yu 2012), we use residual ownership to avoid potential misspecifications in our estimations. To obtain the residual ownership, we first estimate the regression in Eq. (1) for each ownership group as defined in Table 1. Then, we extract the residual terms $\left(\varepsilon_{t}\right)$ from these regressions as our residual measures of ownership.

$$
\begin{aligned}
\text { OWN }_{i t}= & \beta_{0}+\beta_{1} M_{i t-1}+\beta_{2} \text { Price }_{i t-1}+\beta_{3} M_{i t-1}+\beta_{4} \text { Age }_{i t} \\
& +\beta_{5} \text { Volatility }_{i t-2, t}+\beta_{6} \text { Turnover }_{i t}+\beta_{7} \text { Momentum }_{i t-2, t} \\
& +\beta_{8} \text { Momentum }_{i t-12, t-3}+\varepsilon_{i t}
\end{aligned}
$$

where $O W N_{t}$ institutional ownership, measured as the total value of equity held by each institution divided by the market capitalization of the firm at the end of the fiscal year; $M V_{t-1}$ the market value of equity at the beginning of the fiscal year; Price $_{t-1}$ share price at the beginning of the fiscal year; $M B_{t-1}$ market-to-book ratio at the beginning of the fiscal year, calculated as the book value of total assets minus the book value of equity plus the market value of equity divided by the book value of total assets; Age $e_{t}$ The natural logarithm of firm age, measured as the number of years a firm is listed in the Borsa Istanbul; Volatility $_{t-2, t}$ variance of monthly returns from year $t-2$ to year $t$; Turnover $_{t}$ average daily trading volume at the end of the fiscal year divided by the number of ordinary shares outstanding; Momentum ${ }_{t-2, t}$ Gross stock returns for 3 months prior to the end of the fiscal year; Momentum Mo-12,t-3 gross stock returns for 9 months ending 3 months prior to the end of the fiscal year; $i$ firm subscript; $t$ year subscript.

\footnotetext{
${ }^{3}$ Law No. 6493 on Payment and Security Settlement Systems, Payment Services and Electronic Money Institutions.
} 
Table 1 Definitions of the variables

\begin{tabular}{|c|c|}
\hline DIWON $_{t-1}$ & Percentage ownership of domestic institutional investors at the beginning of fiscal year \\
\hline FIWON $_{t-1}$ & Percentage ownership of foreign institutional investors at the beginning of the fiscal year \\
\hline $\mathrm{FCOWN}_{\mathrm{t}-1}$ & Percentage ownership of foreign corporate investors at the beginning of fiscal year \\
\hline FFOWN $_{\mathrm{t}-1}$ & Percentage ownership of foreign funds at the beginning of fiscal year \\
\hline RDIWON $_{\mathrm{t}-1}$ & $\begin{array}{l}\text { Residual percentage ownership of domestic institutional investors at the beginning of fiscal } \\
\text { year }\end{array}$ \\
\hline RFIWON $_{t-1}$ & $\begin{array}{l}\text { Residual percentage ownership of foreign institutional investors at the beginning of fiscal } \\
\text { year }\end{array}$ \\
\hline RFCOWN $_{t-1}$ & Residual percentage ownership of foreign corporate investors at the beginning of fiscal year \\
\hline RFFOWN $_{\mathrm{t}-1}$ & 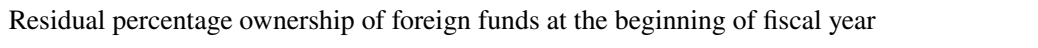 \\
\hline $\mathrm{NI}_{\mathrm{t}}$ & Net income after extraordinary items scaled by beginning of the year market value of equity \\
\hline Ret $_{\mathrm{t}}$ & $\begin{array}{l}\text { 12-month buy-and-hold return during the the f } \\
\text { adjusted monthly stock returns at the fiscal } y\end{array}$ \\
\hline $\mathrm{Neg}_{\mathrm{t}}$ & A dummy variable takes the value of one if Ret is negative, and zero otherwise \\
\hline RISK $_{t-1}$ & $\begin{array}{l}\text { Standard deviation of the residuals from the market model estimated by regressing the } \\
\text { excess return of the stock with the excess return of the market. We use } 3 \text { months treasury } \\
\text { bill rate as risk-free rate and BIST100 index as the market proxy at the beginning of fiscal } \\
\text { year }\end{array}$ \\
\hline $\mathrm{AGE}_{\mathrm{t}-1}$ & $\begin{array}{l}\text { Natural logarithm of the number of years a firm is listed on Borsa Istanbul (former name } \\
\text { IMKB) at the beginning of fiscal year }\end{array}$ \\
\hline $\mathrm{SIZE}_{\mathrm{t}-1}$ & Natural logarithm of the market value of the firm at the beginning of fiscal year \\
\hline $\mathrm{MB}_{\mathrm{t}-1}$ & $\begin{array}{l}\text { The ratio of book value of assets minus the book value of equity plus the market value of } \\
\text { equity to the book value of assets at the beginning of fiscal year }\end{array}$ \\
\hline $\mathrm{LEV}_{\mathrm{t}-1}$ & Total debt divided by the total assets at the beginning of fiscal year \\
\hline $\mathrm{LIT}_{\mathrm{t}-1}$ & $\begin{array}{l}\text { A dummy variable takes the value of one if the firm belongs to Retailers (ICB sector code } \\
404010 \text { ), Software and Computer Services (ICB sector code 101010), Technology, Hard- } \\
\text { ware and Equipment (ICB sector code 101020), Pharmaceuticals and Biotechnology (ICB } \\
\text { sector code 201030) sectors, at the beginning of the fiscal year }\end{array}$ \\
\hline
\end{tabular}

This table presents the definitions of the variables used in the study. We do not remark the firm subscript $i$ for brevity

In estimating the specification in Eq. (1), we include firm and year dummies to control for firm-specific fixed and firm-invariant time effects.

\subsection{Measure of conservatism}

In this study, our primary measure of accounting conservatism is the following Basu's (1997) earnings-return specification:

$$
N I_{i t}=\beta_{0}+\beta_{1} N_{e g} g_{i t}+\beta_{2} \operatorname{Ret}_{i t}+\beta_{3} N_{e g} * \operatorname{Ret}_{i t}+\varepsilon_{i t}
$$

where NI Net income after extraordinary items scaled by the beginning-of-year market value of equity; ${ }^{4} \operatorname{Re} 12$-month buy-and-hold return during the fiscal year, measured by compounding market-adjusted monthly stock returns at the fiscal year-end. The

\footnotetext{
${ }^{4}$ We obtain qualitatively similar results when $N I$ is defined as net income before extraordinary items scaled by the beginning-of-year market value of equity.
} 
market-adjusted returns are computed by subtracting the market returns from the stock return $^{5,6}$; Neg A dummy variable that takes the value of one if Ret is negative and zero otherwise.

Basu (1997) provides evidence that earnings are more sensitive to bad news than good news. In this model, negative (positive) returns account for the bad (good) news. The coefficient $\beta_{2}$ is a measure of the sensitivity of earnings to good news while $\left(\beta_{2}+\beta_{3}\right)$ reflects the bad news. As a result, $\beta_{3}$ captures the incremental sensitivity of earnings to bad over good news. Basu (1997) predicts a stronger reaction of earnings to bad rather than good news because accountants have mechanisms to incorporate future losses into financial reports, but not future profits. It is argued that the potential bias and measurement errors associated with the Basu earnings-based model measure are severe (Dietrich et al. 2007; Givoly et al. 2007). For instance, Dietrich et al. (2007) argue that the evidence of conservatism in prior studies cannot be interpreted as evidence of conservatism, but it is attributable to the biased test statistics inherent in the asymmetric timeliness research design. However, the empirical evidence reported by Ball et al. (2013), Ettredge et al. (2012), and Jayaraman (2012) find that the Basu's measure is effective in capturing conditional conservatism at the firm level. Proponents of the Basu earnings-based measure of conditional conservatism argue that the sources of bias raised in the literature can be easily identified and dealt with (Ryan 2006; Khan and Watts 2009; Ball et al. 2013). We use, in Sect. 6.1, the transitory gain and loss components suggested by Ball and Shivakumar (2005) as an alternative measure for accounting conservatism.

\subsection{Empirical model}

To test the relationship between residual foreign institutional ownership and accounting conservatism, we follow prior research (e.g., Lafond and Roychowdhury 2008; LaFond and Watts 2008; Ramalingegowda and Yu 2012) and extend the original specification of Basu (1997) by incorporating the residual ownership and other firm-specific determinants of conservatism. We estimate the following model:

$$
\begin{aligned}
\mathrm{NI}_{i t}= & \beta_{0}+\beta_{1} \text { Neg }_{i t}+\beta_{2} \operatorname{Ret}_{i t}+\beta_{3} \text { Neg }_{i t} * \text { Ret }_{i t}+\beta_{4} \text { RFOWN }_{i t-1} \\
& +\beta_{5} \text { Neg }_{i t} * \text { RFOWN }_{i t-1}+\beta_{6} \text { Ret }_{i t} * \text { RFOWN }_{i t-1} \\
& +\beta_{7} \text { Neg }_{i t} * \text { Ret }_{i t} * \text { RFOWN }_{i t-1}+\beta_{8-12} \text { Controls }_{i t-1} \\
& +\beta_{13-17} \text { Neg }_{i t} * \text { Controls }_{i t-1}+\beta_{18-22} \text { Ret }_{i t} * \text { Controls }_{i t-1} \\
& +\beta_{23-27} \text { Neg }_{i t} * \text { Ret }_{i t} * \text { Controls }_{i t-1}+\varepsilon_{i t}
\end{aligned}
$$

where $R F O W N_{i t-1}$ is the residual ownership by each group of foreign investors as estimated in Eq. (1). In Eq. (3), the main coefficient of interest is $\beta_{7}$, which captures the impact of

\footnotetext{
${ }^{5}$ We use the market-adjusted returns rather than raw returns to control for the impact of market-wide shocks and jumps on firm-specific earnings (Shroff et al. 2013). We take BIST100 index as our proxy for the market, which includes the top 100 listed firms in Borsa Istanbul in terms of market capitalization. When calculating the market-adjusted returns, we include year fixed-effects in all estimations to remove common shocks from both sides of the equation of Basu's model.

${ }^{6}$ In unreported tests, our results are similar if we use 12-month buy-and-hold return, measured by compounding market-adjusted monthly stock returns ending three months after the months after the fiscal yearend.
} 
Table 2 Descriptive statistics

\begin{tabular}{lrrrrrrr}
\hline & Mean & \multicolumn{1}{l}{ SD } & \multicolumn{1}{l}{ P10 } & \multicolumn{1}{l}{ P25 } & Median & P75 & P90 \\
\hline DIOWN $_{\mathrm{t}-1}$ & 0.092 & 0.145 & 0.001 & 0.005 & 0.031 & 0.103 & 0.270 \\
FIOWN $_{\mathrm{t}-1}$ & 0.094 & 0.149 & 0.000 & 0.000 & 0.024 & 0.133 & 0.271 \\
DCOWN $_{\mathrm{t}-1}$ & 0.082 & 0.143 & 0.000 & 0.002 & 0.017 & 0.087 & 0.260 \\
DFOWN $_{\mathrm{t}-1}$ & 0.006 & 0.014 & 0.000 & 0.000 & 0.001 & 0.005 & 0.014 \\
FCOWN $_{\mathrm{t}-1}$ & 0.049 & 0.119 & 0.000 & 0.000 & 0.004 & 0.045 & 0.126 \\
FFOWN $_{\mathrm{t}-1}$ & 0.045 & 0.081 & 0.000 & 0.000 & 0.005 & 0.053 & 0.154 \\
NI $_{\mathrm{t}}$ & 0.040 & 0.262 & -0.168 & -0.025 & 0.051 & 0.123 & 0.218 \\
Ret $_{\mathrm{t}}$ & 0.065 & 0.451 & -0.408 & -0.226 & 0.011 & 0.285 & 0.619 \\
Neg $_{\mathrm{t}}$ & 0.482 & 0.500 & 0.000 & 0.000 & 0.000 & 1.000 & 1.000 \\
RISK $_{\mathrm{t}-1}$ & 0.027 & 0.009 & 0.018 & 0.021 & 0.026 & 0.032 & 0.038 \\
AGE $_{\mathrm{t}-1}$ & 2.646 & 0.539 & 1.946 & 2.398 & 2.773 & 3.045 & 3.178 \\
SIZE $_{\mathrm{t}-1}$ & 18.978 & 1.759 & 16.821 & 17.708 & 18.830 & 20.083 & 21.291 \\
MB $_{\mathrm{t}-1}$ & 1.415 & 1.086 & 0.739 & 0.921 & 1.136 & 1.518 & 2.119 \\
LEV $_{\mathrm{t}-1}$ & 0.218 & 0.195 & 0.000 & 0.047 & 0.182 & 0.349 & 0.485 \\
LIT $_{\mathrm{t}-1}$ & 0.129 & 0.335 & 0.000 & 0.000 & 0.000 & 0.000 & 1.000 \\
\hline
\end{tabular}

This table presents descriptive statistics for the variables employed in the analysis based on the full sample that includes 1618 firm-year observations over 2007-2015. Variable definitions are provided in Table 1. We do not remark the firm subscript $i$ for brevity

residual foreign institutional ownership on accounting conservatism. Following prior research (Ramalingegowda and Yu 2012), we also include residual ownership by domestic investors to mitigate the potential omitted variable concerns.

We also include several other control variables in our baseline specification. We incorporate the natural logarithm of the market capitalization of firms, SIZE, as a proxy for firm size. Since large firms are expected to be better managed, exposed to higher public pressure, and enjoy economies of scale in monitoring self-interest managerial behavior (Himmelberg et al. 1999; Chen and Yur-Austin 2007), we expect that their demand for conservatism to be low (LaFond and Watts 2008; Ramalingegowda and Yu 2012). It is argued that high levered firms are more likely to experience greater conflicts between debtholders and shareholders, which in turn increases the demand for conservative reporting (Ball and Shivakumar 2005; Khan and Watts 2009). To account for this, we incorporate total debt scaled by total assets, $L E V$, as a proxy for leverage. We include market-to-book ratio, $M B$, to control for the impact of growth options. Firms with high growth options have greater volatility in cash flows and greater agency conflicts between managers and shareholders.

Given that conservatism is to some extent a response to agency problems, we expect a positive relationship between $M B$ and conservatism (LaFond and Watts 2008). Khan and Watts (2009) argue that conservatism decreases with firm age, $A G E$, since younger firms face greater investment opportunities and growth options (Giner and Ress 2001; Ball and Shivakumar 2005). We also include stock return volatility, RISK, to control for uncertainty about the financial environment in which firms operate. Khan and Watts (2009) find that conservatism increases with the firm-specific uncertainty due to its negative correlation with the stock returns. Finally, high litigation risk, LIT, is expected to increase the demand for conservative reporting. Following Ramalingegowda and Yu (2012) and LaFond and Roychowdhury (2008), we use an indicator variable if the firm operates in an industry with 


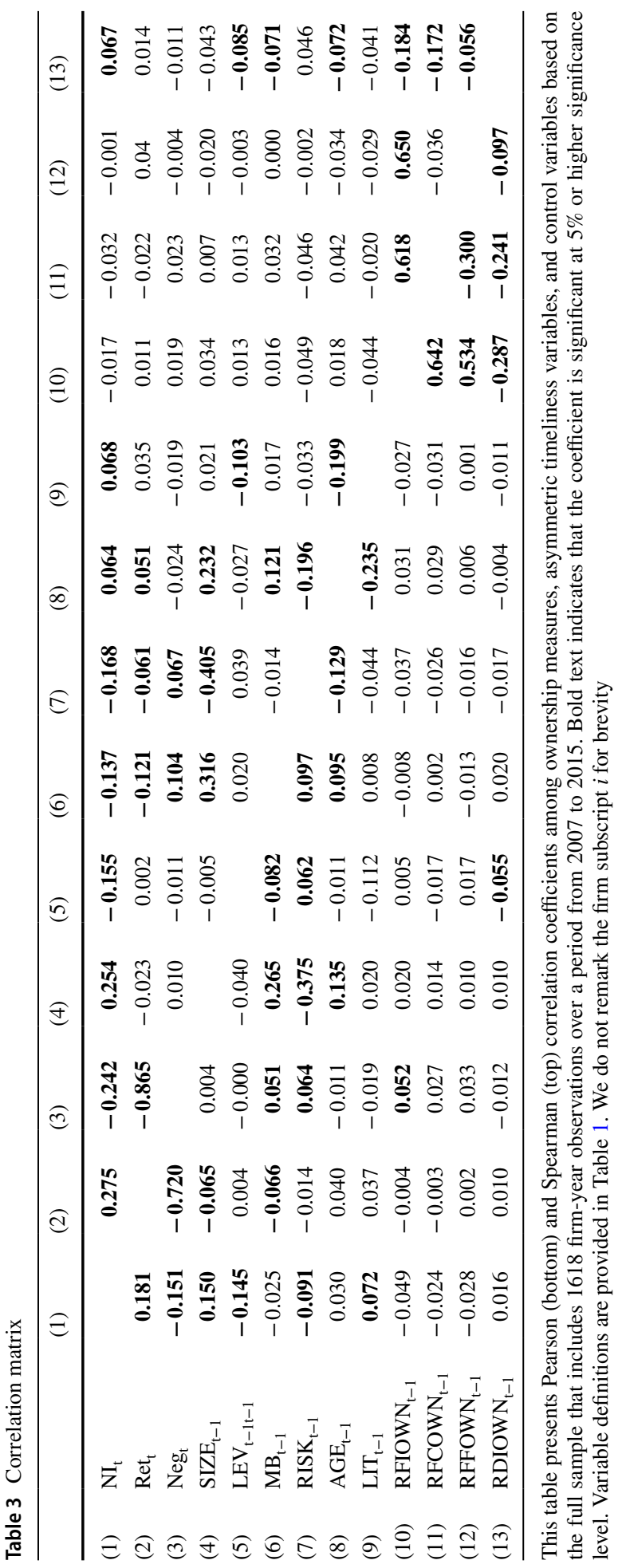


high litigation risk. ${ }^{7}$ We also include year dummies into our model to control for firminvariant time effects. Variable definitions are provided in Table 1.

\section{Empirical results}

\subsection{Descriptive statistics}

Table 2 reports the descriptive statistics for the main variables used in the analysis. The average raw ownership of domestic, DIOWN, and foreign institutional investors, FIOWN, are respectively $9.2 \%$ and $9.4 \%$. The holdings of foreign corporate investors, $F C O W N$, and foreign funds, FFOWN, are $4.9 \%$ and $4.5 \%$, respectively. This figure implies that the average ownership of foreign funds and foreign corporate investors are divided almost equally among our sample firms. Table 3 reports the Pearson and Spearman correlation coefficients among the variables used in this study. The correlation coefficients among control variables are generally low. The highest and lowest correlation coefficients among control variables are between SIZE and $M B$ (0.32) and SIZE and RISK (-0.40), respectively.

\subsection{Multivariate results}

Table 4 reports the results of the ordinary least squares (OLS) regressions for H1. All regressions are estimated using robust standard errors clustered at the firm and year levels to correct for heteroscedasticity and serial dependence (Petersen 2009; Gow et al. 2010). Throughout the paper, all significance levels are two-tailed. In Model (1), we present the results of the baseline analysis where we provide the estimated coefficients for all variables except for those of ownership. We find the estimated coefficients are insignificant at any level. The results suggest that firm-specific accounting variables do not explain the variation in conservative reporting for the firms in Turkey. In other words, the dynamics of reporting practices concerning conservative reporting in emerging markets are different from those in developed countries. In Model (2), we report the results of the specification where the association between foreign institutional (residual) ownership and accounting conservatism. For brevity, we do not present the estimated coefficients of stand-alone control variables and their interactions with Ret and Neg. The results show that the coefficient of $\operatorname{Ret}_{i t} * \operatorname{RFIOWN}_{i t-1}$ is positive and statistically significant at the 5\% level while, consistent with our predictions, the estimated coefficient of $\operatorname{Neg}_{i t} * \operatorname{Ret}_{i t} * R F I O W N_{i t-1}$ is positive and statistically significant at the $1 \%$ level. The finding suggests that firms recognize economic losses more quickly than economic gains with the increase of foreign institutional ownership. This is in support of the view that accounting conservatism is an effective corporate governance device that is more likely to counter the managerial incentives to overstate earnings and reap benefits at the expense of minority shareholders, which is consistent with $\mathrm{H}_{1}$. In contrast, we find no evidence that higher residual ownership by domestic institutional investors is associated with accounting conservatism. The estimated coefficient of $\mathrm{Neg}_{i t} * \operatorname{Ret}_{i t} * \mathrm{RDIOWN}_{i t-1}$ is insignificant at any conventional significance level. To the extent that domestic investors have an informational advantage over foreign

\footnotetext{
7 We also perform additional estimations by excluding the LIT from our model. Our results remain qualitatively similar.
} 
Table 4 The effect of foreign ownership on accounting conservatism

\begin{tabular}{|c|c|c|c|c|c|}
\hline & Exp. sign & (1) & (2) & (3) & (4) \\
\hline Ret $_{t}$ & & $\begin{array}{l}0.530 \\
(0.825)\end{array}$ & $\begin{array}{l}0.671 \\
(0.807)\end{array}$ & $\begin{array}{l}0.635 \\
(0.841)\end{array}$ & $\begin{array}{l}0.525 \\
(0.792)\end{array}$ \\
\hline $\mathrm{Neg}_{\mathrm{t}}$ & & $\begin{array}{l}0.052 \\
(0.241)\end{array}$ & $\begin{array}{l}0.060 \\
(0.245)\end{array}$ & $\begin{array}{l}0.069 \\
(0.247)\end{array}$ & $\begin{array}{l}0.049 \\
(0.247)\end{array}$ \\
\hline $\operatorname{Ret}_{t} * \mathrm{Neg}_{\mathrm{t}}$ & + & $\begin{array}{l}0.108 \\
(1.232)\end{array}$ & $\begin{array}{l}-0.021 \\
(1.184)\end{array}$ & $\begin{array}{l}0.012 \\
(1.198)\end{array}$ & $\begin{array}{l}0.148 \\
(1.214)\end{array}$ \\
\hline RFOWN $_{t-1}$ & & & $\begin{array}{l}-0.014 \\
(0.320)\end{array}$ & $\begin{array}{l}0.239 \\
(0.330)\end{array}$ & $\begin{array}{l}-0.119 \\
(0.333)\end{array}$ \\
\hline Ret $_{\mathrm{t}} * \mathrm{RFIOWN}_{\mathrm{t}-1}$ & & & $\begin{array}{l}-1.715^{* *} \\
(0.520)\end{array}$ & & \\
\hline $\mathrm{RET}_{\mathrm{t}} * \mathrm{RFCOWN}_{\mathrm{t}-1}$ & & & & $\begin{array}{l}-1.431^{*} \\
(0.656)\end{array}$ & \\
\hline Ret $_{t} *$ RFFOWN $_{t-1}$ & & & & & $\begin{array}{l}-1.225^{*} \\
(0.613)\end{array}$ \\
\hline $\mathrm{Neg}_{\mathrm{t}} *$ RFIOWN $\mathrm{t}_{\mathrm{t}-1}$ & & & $\begin{array}{l}0.061 \\
(0.586)\end{array}$ & & \\
\hline $\mathrm{Neg}_{\mathrm{t}} * \mathrm{RFCOWN}_{\mathrm{t}-1}$ & & & & $\begin{array}{l}-0.300 \\
(0.555)\end{array}$ & \\
\hline $\mathrm{Neg}_{\mathrm{t}} * \mathrm{RFFOWN}_{\mathrm{t}-1}$ & & & & & $\begin{array}{l}0.186 \\
(0.405)\end{array}$ \\
\hline $\operatorname{Ret}_{t} * \mathrm{Neg}_{\mathrm{t}} * \mathrm{RFIOWN}_{\mathrm{t}-1}$ & + & & $\begin{array}{l}1.701 * * * \\
(0.195)\end{array}$ & & \\
\hline $\mathrm{Ret}_{\mathrm{t}} * \mathrm{Neg}_{\mathrm{t}} * \mathrm{RFCOWN}_{\mathrm{t}-1}$ & + & & & $\begin{array}{l}1.305 * * \\
(0.424)\end{array}$ & \\
\hline Ret $_{t} * \mathrm{Neg}_{\mathrm{t}} *$ RFFOWN & $?$ & & & & $\begin{array}{l}1.010 \\
(0.930)\end{array}$ \\
\hline Ret $_{t} * \mathrm{Neg}_{\mathrm{t}} * \mathrm{RDIOWN}_{\mathrm{t}-1}$ & ? & $\begin{array}{l}-0.859 \\
(0.599)\end{array}$ & $\begin{array}{l}0.464 \\
(0.566)\end{array}$ & $\begin{array}{l}0.039 \\
(0.719)\end{array}$ & $\begin{array}{l}-0.729 \\
(0.573)\end{array}$ \\
\hline $\operatorname{Ret}_{\mathrm{t}} * \mathrm{Neg}_{\mathrm{t}} * \mathrm{SIZE}_{\mathrm{t}-1}$ & - & $\begin{array}{l}0.004 \\
(0.070)\end{array}$ & $\begin{array}{l}0.013 \\
(0.068)\end{array}$ & $\begin{array}{l}0.012 \\
(0.068)\end{array}$ & $\begin{array}{l}0.001 \\
(0.070)\end{array}$ \\
\hline $\operatorname{Ret}_{t} * \mathrm{Neg}_{\mathrm{t}} * \mathrm{LEV}_{\mathrm{t}-1}$ & + & $\begin{array}{l}-0.623 \\
(0.550)\end{array}$ & $\begin{array}{c}-0.583 \\
(0.554)\end{array}$ & $\begin{array}{c}-0.576 \\
(0.559)\end{array}$ & $\begin{array}{l}-0.651 \\
(0.554)\end{array}$ \\
\hline $\operatorname{Ret}_{\mathrm{t}} * \mathrm{Neg}_{\mathrm{t}} * \mathrm{MB}_{\mathrm{t}-1}$ & - & $\begin{array}{l}0.007 \\
(0.041)\end{array}$ & $\begin{array}{l}0.001 \\
(0.036)\end{array}$ & $\begin{array}{l}0.002 \\
(0.037)\end{array}$ & $\begin{array}{l}0.008 \\
(0.040)\end{array}$ \\
\hline $\operatorname{Ret}_{t} * \operatorname{Neg}_{t} * \operatorname{RISK}_{t-1}$ & + & $\begin{array}{l}-6.686 \\
(5.899)\end{array}$ & $\begin{array}{c}-8.575 \\
(6.545)\end{array}$ & $\begin{array}{c}-7.374 \\
(6.488)\end{array}$ & $\begin{array}{l}-7.807 \\
(5.682)\end{array}$ \\
\hline $\operatorname{Ret}^{*} \mathrm{Neg}^{*} \mathrm{AGE}_{\mathrm{t}-1}$ & - & $\begin{array}{l}0.035 \\
(0.118)\end{array}$ & $\begin{array}{l}0.033 \\
(0.115)\end{array}$ & $\begin{array}{l}0.015 \\
(0.109)\end{array}$ & $\begin{array}{l}0.050 \\
(0.127)\end{array}$ \\
\hline Ret*Neg*LIT $_{\mathrm{t}-1}$ & + & $\begin{array}{l}-0.061 \\
(0.135)\end{array}$ & $\begin{array}{l}-0.057 \\
(0.120)\end{array}$ & $\begin{array}{l}-0.061 \\
(0.134)\end{array}$ & $\begin{array}{l}-0.056 \\
(0.122)\end{array}$ \\
\hline Controls $_{t-1}$ & & Included & Included & Included & Included \\
\hline Ret $_{\mathrm{t}}{ }^{*}$ controls $_{\mathrm{t}-1}$ & & Included & Included & Included & Included \\
\hline $\mathrm{Neg}_{\mathrm{t}} *$ controls $_{\mathrm{t}-1}$ & & Included & Included & Included & Included \\
\hline $\mathrm{R}^{2}$ & & 0.136 & 0.150 & 0.141 & 0.141 \\
\hline \# observations & & 1618 & 1618 & 1618 & 1618 \\
\hline
\end{tabular}


Table 4 (continued)

This table reports results from the pooled OLS regressions, where the dependent variable is $N I$, defined as net income after extraordinary items, scaled by the beginning of the year market value of equity. All estimations include year dummies. Variable definitions are provided in Table 1. Cluster-adjusted robust standard errors are in parenthesis. Standard errors are clustered at the firm and year level. ***, **, * denote significance level at $1 \%, 5 \%$, and $10 \%$, respectively (two-tailed). We do not remark the firm subscript $i$ for brevity

investors and they may have a supplementary access to internal financial and management information through alternative communication channels that may substitute for conservatism. Another alternative explanation is that local investors may not have the incentives to closely monitor corporate managers or pressure them for changes (Chen et al. 2007). Adopting more conservative reporting may harm their business relations with management (Gillan and Starks 2003).

Next, we investigate whether foreign corporations' demand for conservatism is different from that of foreign funds. We carry out this analysis by separating the residual ownership by foreign institutions into two distinct sub-groups, namely corporations and funds' residual ownership, and test their impact on conservative reporting. We group foreign institutional investors into foreign corporate investors and foreign funds using the classification provided by Borsa Istanbul and Capital Markets Board of Turkey. At the end of each fiscal year, Borsa Istanbul reports the ownership of foreign investors in listed firms in Borsa Istanbul, classifying ownership as foreign corporate ownership, foreign funds ownership, and foreign individual ownership. Foreign corporate ownership includes all foreign corporations and limited liability companies, whereas foreign funds ownership includes investment funds. Different from the US and the UK studies, we are unable to categorize foreign institutional investors as dedicated and transient or as hedge funds and pension funds due to unavailability of these data. We divide the ownership amount of each group by the total market capitalization of the firm to calculate the raw ownership ratio. ${ }^{8}$ Then, we estimate Eq. (1) for each group and predict the residuals as our primary measure of foreign corporate and funds ownership.

The results are reported in Models (3) and (4). The estimated coefficient for residual ownership by foreign corporations in Model (3) is positive and significant at the $5 \%$ level, while the estimated coefficient of $\mathrm{Neg}_{i t} * \operatorname{Ret}_{i t} * R F F O W N_{i t-1}, \beta_{7}$, given in Model (4) is positive but not significant. These results possibly indicate that firms with higher corporate foreign ownership leads to greater conservatism in financial reporting, consistent with $\mathrm{H}_{2}$. It seems that disaggregating foreign institutions as foreign corporations and funds provides additional insights into the understanding of the sources of the demand for conservatism.

Taken together, the regression results reported in Table 4 are supportive of our conjuncture that higher foreign institutional ownership makes earnings more asymmetrically timely in recognizing bad news than good news. Our results also suggest that the demand for conservative financial reporting arises mainly from foreign corporate investors rather than foreign funds or domestic investors.

\footnotetext{
${ }^{8}$ We did not include foreign individual investors into our analysis for two reasons. First, we find that the total shares held by foreign individual investors is less than $1 \%$ of the free-float market capitalization of Borsa Istanbul. Second, individual investors may not value or extract the benefits associated with conservatism.
} 


\subsection{Investee firm characteristics and accounting conservatism}

In this section, we further test how the relationship between foreign institutional ownership and conservatism varies with the degrees of information asymmetry and growth opportunities. Following earlier work, we use bid-ask-spread, SPREAD, and firm size, SIZE, as proxies of information asymmetry (see, e.g., LaFond and Watts 2008; Ramalingegowda and Yu 2012; Kim et al. 2013). We measure SPREAD as the yearly average of daily bid-ask spread over the prior year, computed as [(ask - bid)/(ask + bid $) / 2]$ for each firm. We partition firms based on the median values of SPREAD and SIZE. We label firms with above-median values of SPREAD and SIZE as firms with high information asymmetry. We estimate Eq. (3) for each group and test whether the relationship between foreign institutional ownership and conservatism varies across the sub-groups. Similarly, we partition firms based on the median value of the market-to-book ratio, $M B$. Specifically, firms with above median (less than or equal the median value) $M B$ form high-growth (low-growth) sub-group.

Given that smaller firms and firms with high bid-ask spread are expected to experience greater agency costs (Ramalingegowda and Yu 2012), we expect that the positive relationship between residual ownership by foreign institutions and accounting conservatism to be more pronounced among small firms and firms with high bid-ask spreads (Kim et al. 2016; Lel 2017). This is because monitoring the managers of small firms is likely to be costly because they are less visible, less exposed to political intrusion and public pressure than large firms (Watts and Zimmerman 1990). Also, a higher bid-ask spread is likely to indicate higher information asymmetry between informed and less informed investors in the capital market (Kim et al. 2013).

The results in Models (2) and (3) of Table 5 show that the estimated coefficient of $\mathrm{Neg}_{i t} * \operatorname{Ret}_{i t} * \mathrm{RFIOWN}_{i t-1}$ is positive and significant at $10 \%$ for firms with high bid-ask spread and small firms sub-groups. These results indicate that the positive impact of foreign institutions ownership on conservative reporting is only evident for firms with greater information asymmetry In Models (5) and (6), the positive association between conservatism and residual ownership by foreign institutions holds only for the high-growth sub-groups. ${ }^{9}$

\section{Additional analyses}

\subsection{Alternative measure for accounting conservatism}

We use thus far the extended version of Basu's (1997) model to measure conservatism. It is, however, argued that the potential bias and measurement errors associated with the Basu's earnings-based model measure could be significant (Dietrich et al. 2007; Givoly et al. 2007).

As a robustness check, we employ an alternative firm-year measure for conservatism, which is a non-return measure that is based on the current earnings-changes model suggested by Ball and Shivakumar (2005). Based on the asymmetric persistence of negative earnings changes, Basu (1997) finds that negative changes in earnings (i.e. transitory loss

\footnotetext{
9 We continue our analysis only for the foreign corporate investors since the main driver for conservatism arises from the corporate investors than funds.
} 
Table 5 The effect of foreign ownership on accounting conservatism and partitioned by the level of information asymmetry and growth opportunities

\begin{tabular}{|c|c|c|c|c|c|c|c|}
\hline & \multirow[t]{2}{*}{ Exp. sign } & \multicolumn{2}{|l|}{ Firm size } & \multicolumn{2}{|c|}{ Bid-ask spread } & \multicolumn{2}{|c|}{ Growth opportunities } \\
\hline & & $\begin{array}{l}\text { (1) } \\
\text { Large }\end{array}$ & $\begin{array}{l}(2) \\
\text { Small }\end{array}$ & $\begin{array}{l}\text { (3) } \\
\text { High }\end{array}$ & $\begin{array}{l}\text { (4) } \\
\text { Low }\end{array}$ & $\begin{array}{l}(5) \\
\text { Low }\end{array}$ & $\begin{array}{l}\text { (6) } \\
\text { High }\end{array}$ \\
\hline $\operatorname{Ret}_{\mathrm{t}}$ & & $\begin{array}{l}0.619 \\
(0.647)\end{array}$ & $\begin{array}{l}1.887 \\
(1.988)\end{array}$ & $\begin{array}{l}1.665 \\
(1.009)\end{array}$ & $\begin{array}{l}-1.113 \\
(0.716)\end{array}$ & $\begin{array}{l}-0.890 \\
(0.856)\end{array}$ & $\begin{array}{l}1.856^{* *} \\
(0.786)\end{array}$ \\
\hline $\mathrm{Neg}_{\mathrm{t}}$ & & $\begin{array}{l}0.426 \\
(0.309)\end{array}$ & $\begin{array}{l}-0.521 \\
(1.003)\end{array}$ & $\begin{array}{l}-0.068 \\
(0.499)\end{array}$ & $\begin{array}{l}-0.080 \\
(0.318)\end{array}$ & $\begin{array}{l}-0.325 \\
(0.522)\end{array}$ & $\begin{array}{l}0.375^{*} \\
(0.168)\end{array}$ \\
\hline $\operatorname{Ret}_{t} * \mathrm{Neg}_{\mathrm{t}}$ & + & $\begin{array}{l}0.101 \\
(0.969)\end{array}$ & $\begin{array}{l}-3.063 \\
(2.768)\end{array}$ & $\begin{array}{l}-1.942 \\
(1.717)\end{array}$ & $\begin{array}{l}2.642 * * * \\
(0.711)\end{array}$ & $\begin{array}{l}1.926 \\
(1.184)\end{array}$ & $\begin{array}{l}-1.444 \\
(1.274)\end{array}$ \\
\hline RFOWN $_{t-1}$ & & $\begin{array}{l}-0.242 \\
(0.158)\end{array}$ & $\begin{array}{l}-0.033 \\
(0.935)\end{array}$ & $\begin{array}{l}0.116 \\
(0.765)\end{array}$ & $\begin{array}{l}-0.413^{*} \\
(0.184)\end{array}$ & $\begin{array}{l}-0.469 \\
(0.604)\end{array}$ & $\begin{array}{l}0.507 \\
(0.438)\end{array}$ \\
\hline Ret $_{t} *$ RFIOWN $_{t-1}$ & & $\begin{array}{l}-0.090 \\
(0.443)\end{array}$ & $\begin{array}{l}-2.363^{*} \\
(1.178)\end{array}$ & $\begin{array}{l}-2.648^{*} \\
(1.321)\end{array}$ & $\begin{array}{l}0.410 \\
(0.559)\end{array}$ & $\begin{array}{l}-1.184^{*} \\
(0.566)\end{array}$ & $\begin{array}{l}-2.511 \\
(1.533)\end{array}$ \\
\hline $\mathrm{Neg}_{\mathrm{t}} * \mathrm{RFIOWN}_{\mathrm{t}-1}$ & & $\begin{array}{l}0.514 \\
(0.365)\end{array}$ & $\begin{array}{l}0.362 \\
(1.336)\end{array}$ & $\begin{array}{l}-0.050 \\
(1.089)\end{array}$ & $\begin{array}{l}0.346 \\
(0.503)\end{array}$ & $\begin{array}{l}0.331 \\
(1.006)\end{array}$ & $\begin{array}{l}-0.304 \\
(0.499)\end{array}$ \\
\hline $\operatorname{Ret}_{t} * \mathrm{Neg}_{t} * \mathrm{RFIOWN}_{\mathrm{t}-1}$ & + & $\begin{array}{l}0.622 \\
(0.708)\end{array}$ & $\begin{array}{l}2.452 * \\
(1.285)\end{array}$ & $\begin{array}{l}2.034 * \\
(0.984)\end{array}$ & $\begin{array}{l}-0.360 \\
(0.534)\end{array}$ & $\begin{array}{l}0.808 \\
(1.767)\end{array}$ & $\begin{array}{l}2.922 * \\
(1.540)\end{array}$ \\
\hline Ret $_{t} * \mathrm{Neg}_{t} * \mathrm{RDIOWN}_{\mathrm{t}-1}$ & $?$ & $\begin{array}{l}0.538 \\
(0.492)\end{array}$ & $\begin{array}{l}-0.085 \\
(0.758)\end{array}$ & $\begin{array}{l}0.228 \\
(0.718)\end{array}$ & $\begin{array}{l}0.072 \\
(0.526)\end{array}$ & $\begin{array}{l}1.121 \\
(1.371)\end{array}$ & $\begin{array}{l}0.211 \\
(0.749)\end{array}$ \\
\hline $\operatorname{Ret}_{t} * \mathrm{Neg}_{t} * \operatorname{SIZE}_{\mathrm{t}-1}$ & - & $\begin{array}{l}-0.017 \\
(0.033)\end{array}$ & $\begin{array}{l}0.218 \\
(0.175)\end{array}$ & $\begin{array}{l}0.128 \\
(0.091)\end{array}$ & $\begin{array}{l}-0.127 * * * \\
(0.036)\end{array}$ & $\begin{array}{l}-0.080 \\
(0.060)\end{array}$ & $\begin{array}{l}0.103 \\
(0.095)\end{array}$ \\
\hline $\operatorname{Ret}_{t} * \operatorname{Neg}_{t} * \operatorname{LEV}_{t-1}$ & + & $\begin{array}{l}-0.015 \\
(0.336)\end{array}$ & $\begin{array}{l}-0.875 \\
(0.852)\end{array}$ & $\begin{array}{l}-0.977 \\
(0.831)\end{array}$ & $\begin{array}{l}0.155 \\
(0.385)\end{array}$ & $\begin{array}{l}-0.098 \\
(0.514)\end{array}$ & $\begin{array}{l}-0.948 \\
(0.854)\end{array}$ \\
\hline $\operatorname{Ret}_{t} * \mathrm{Neg}_{\mathrm{t}} * \mathrm{MB}_{\mathrm{t}-1}$ & - & $\begin{array}{l}0.012 \\
(0.028)\end{array}$ & $\begin{array}{l}0.156 \\
(0.157)\end{array}$ & $\begin{array}{l}-0.019 \\
(0.055)\end{array}$ & $\begin{array}{l}0.058 \\
(0.042)\end{array}$ & $\begin{array}{l}-0.384 \\
(0.473)\end{array}$ & $\begin{array}{l}-0.045 \\
(0.034)\end{array}$ \\
\hline $\operatorname{Ret}_{t} * \operatorname{Neg}_{t} * \operatorname{RISK}_{\mathrm{t}-1}$ & + & $\begin{array}{l}-9.099 \\
(6.290)\end{array}$ & $\begin{array}{l}-13.641 \\
(9.710)\end{array}$ & $\begin{array}{l}-6.749 \\
(8.618)\end{array}$ & $\begin{array}{l}-14.812 \\
(9.175)\end{array}$ & $\begin{array}{l}-19.565^{*} \\
(8.834)\end{array}$ & $\begin{array}{l}3.280 \\
(6.363)\end{array}$ \\
\hline $\operatorname{Ret}_{t} * \operatorname{Neg}_{t} * \mathrm{AGE}_{\mathrm{t}-1}$ & - & $\begin{array}{l}0.158 \\
(0.154)\end{array}$ & $\begin{array}{l}-0.166 \\
(0.235)\end{array}$ & $\begin{array}{l}-0.030 \\
(0.262)\end{array}$ & $\begin{array}{l}0.008 \\
(0.101)\end{array}$ & $\begin{array}{l}0.140 \\
(0.167)\end{array}$ & $\begin{array}{l}-0.121 \\
(0.206)\end{array}$ \\
\hline $\operatorname{Ret}_{t}^{*} \operatorname{Neg}_{t} * \operatorname{LIT}_{t-1}$ & + & $\begin{array}{l}-0.075 \\
(0.115)\end{array}$ & $\begin{array}{l}-0.036 \\
(0.264)\end{array}$ & $\begin{array}{l}0.095 \\
(0.247)\end{array}$ & $\begin{array}{l}-0.168 \\
(0.215)\end{array}$ & $\begin{array}{l}-0.179 \\
(0.407)\end{array}$ & $\begin{array}{l}0.008 \\
(0.125)\end{array}$ \\
\hline Controls $_{t-1}$ & & Included & Included & Included & Included & Included & Included \\
\hline Ret $_{t} *$ Controls $_{t-1}$ & & Included & Included & Included & Included & Included & Included \\
\hline $\mathrm{Neg}_{\mathrm{t}} *$ Controls $_{\mathrm{t}-1}$ & & Included & Included & Included & Included & Included & Included \\
\hline $\mathrm{R}^{2}$ & & 0.193 & 0.174 & 0.166 & 0.244 & 0.240 & 0.158 \\
\hline \# observations & & 809 & 809 & 809 & 809 & 809 & 809 \\
\hline
\end{tabular}

This table reports results from the pooled OLS regressions, where the dependent variable is $N I$, defined as net income after extraordinary items, scaled by the beginning of the year market value of equity. All estimations include year dummies. Variable definitions are provided in Table 1. Cluster-adjusted robust standard errors are in parenthesis. Standard errors are clustered at the firm and year level. ***, **, * denote significance level at $1 \%, 5 \%$, and $10 \%$, respectively (two-tailed). We do not remark the firm subscript $i$ for brevity

components in earnings) are less persistent than positive changes in earnings (i.e. transitory gain components in earnings). Using the transitory gain and loss components as a 


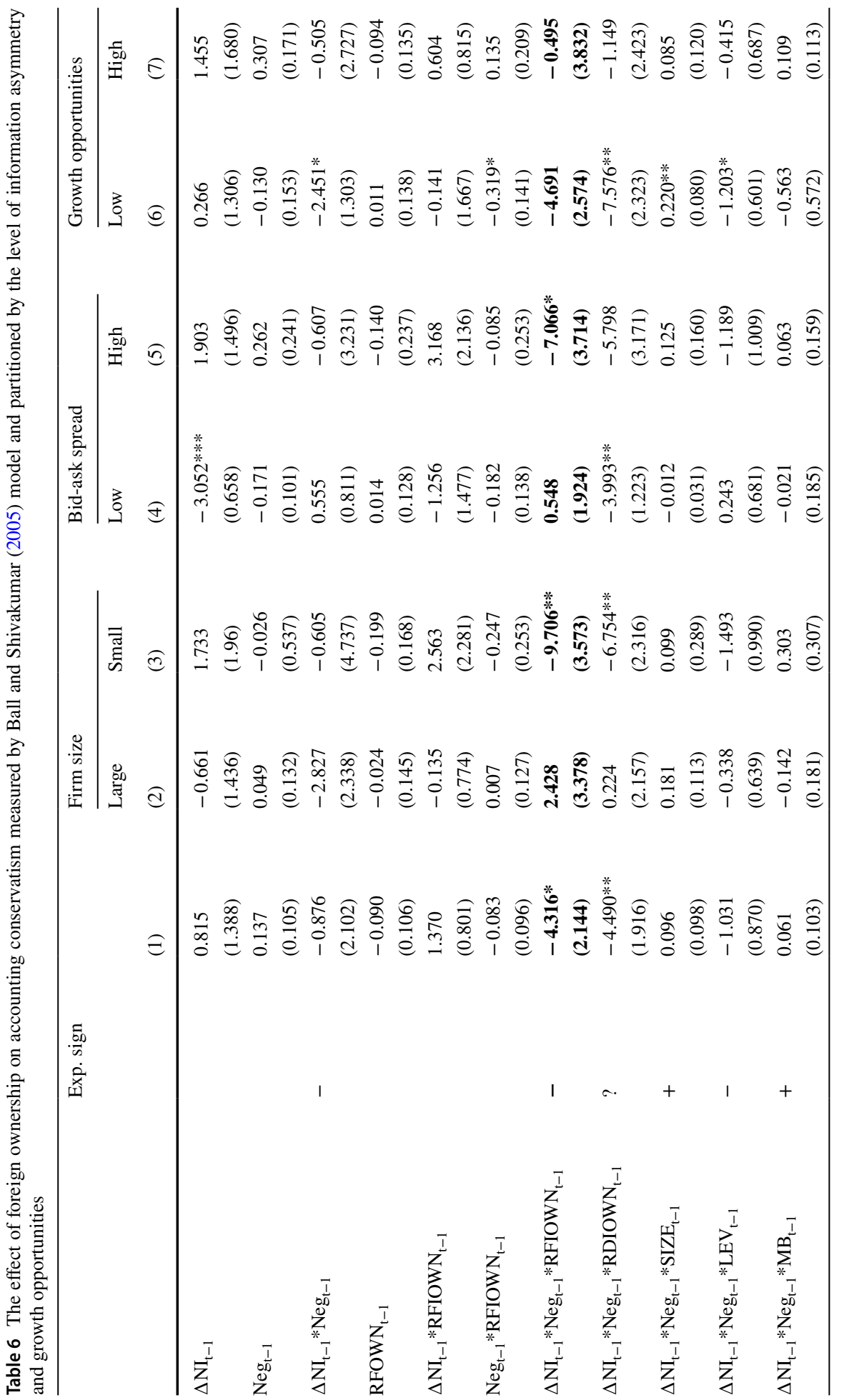




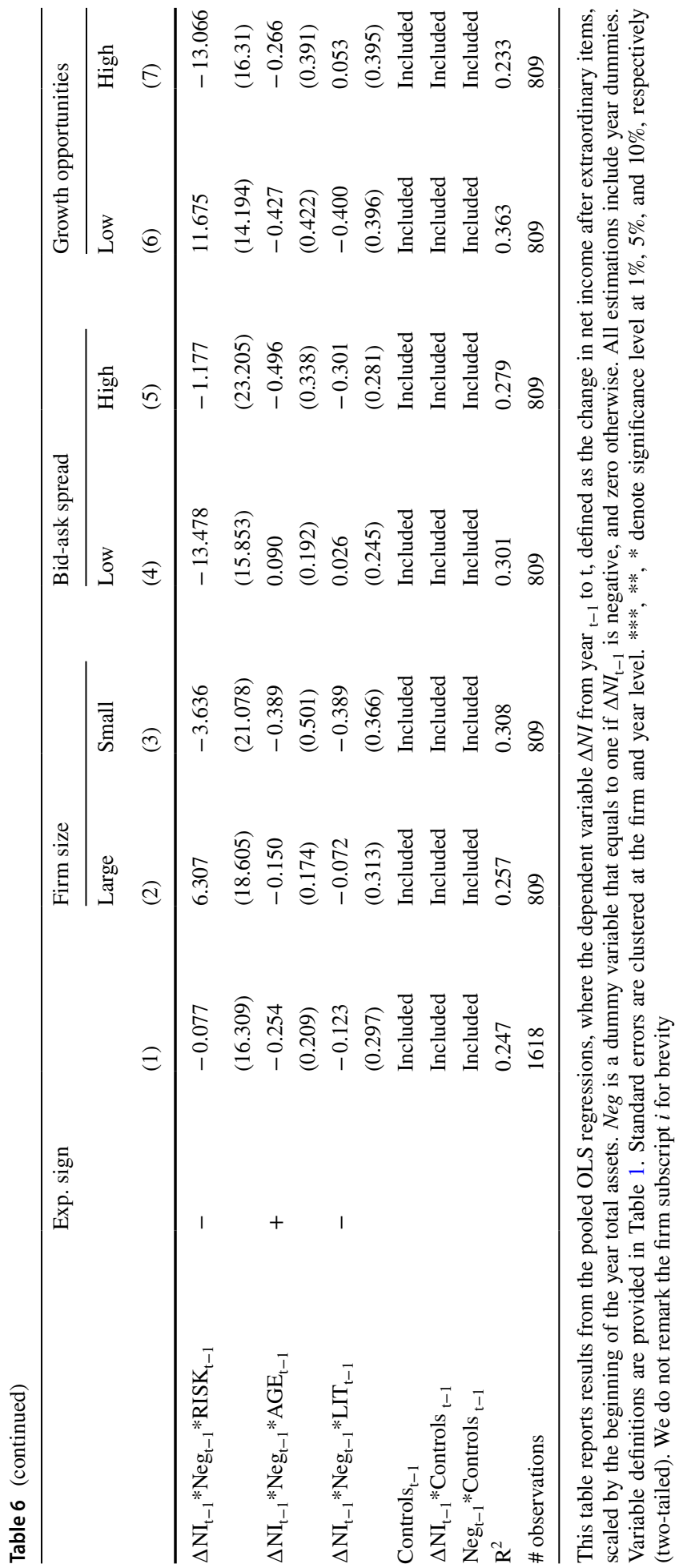


measure of timeliness in loss recognition, Ball and Shivakumar (2005) estimate the following model:

$$
\Delta N I_{i t}=\beta_{0}+\beta_{1} N e g_{i t-1}+\beta_{2} \Delta N I_{i t-1}+\beta_{3} \Delta N I_{i t-1} * N e g_{i t-1}+\varepsilon_{i t},
$$

where $\Delta N I$ is the change in earnings before extraordinary items from year $t-1$ to year $t$, deflated by the beginning book value of equity; and Neg is a dummy variable that takes the value of one if prior-year change $\Delta N I$ is negative, and zero otherwise.

To test the relation between foreign institutional ownership and accounting conservatism in a similar framework, we extend the original specification of Ball and Shivakumar (2005) by incorporating the residual ownership by foreign and domestic institutions and other firm-specific determinants of conservatism to the following model:

$$
\begin{aligned}
\Delta N I_{i t}= & \beta_{0}+\beta_{1} \text { Neg }_{i t-1}+\beta_{2} \Delta N I_{i t-1}+\beta_{3} \text { Neg }_{i t-1} * \Delta \text { NI I }_{i t-1}+\beta_{4} \text { RFIOWN }_{i t-1} \\
& +\beta_{5} \text { Neg }_{i t-1} * \text { RFIOWN } \\
& * \text { RFIOWN }_{i t-1}+\beta_{6} \Delta N \text { II }_{i t-1} * \text { RFIOWN }_{i t-1}+\beta_{7} \text { Neg }_{i t-1} * \Delta N I_{i t-1} \\
& * \text { Controls }_{i t-1}+\beta_{23-27} \text { Neg }_{i t-1} * \Delta N I_{i t-1} * \text { Controls }_{i t-1}+\varepsilon_{i t}
\end{aligned}
$$

The results are reported in Table 6. The estimated coefficients in Model (1) confirm the positive relation between foreign institutional ownership and conservatism, albeit at a lower significance level. Specifically, the coefficient of $N_{e} g_{i t} * \Delta N I_{i t} * R F I O W N_{i t-1}$ is negative and significant at the $10 \%$ level, suggesting that foreign institutional ownership is associated with less persistent transitory losses (i.e., higher earnings conservatism). In line with the results documented earlier, the findings in Models (3) and (5) confirms that the demand on conservatism by foreign institutions is more apparent when information asymmetry is acute. Specifically, the estimated coefficient of $\mathrm{Neg}_{i t} * \Delta N I_{i t} * R F I O W N_{i t-1}$ is still negative and significant for small firms and firms with high bid-ask spread (i.e., firms with high information asymmetry). However, it seems that there are no differences between the high- and low-growth subgroups. These findings suggest that our results hold irrespective of the measure of conservatism. In sum, the findings of the analysis given in Table 6 lend support to $\mathrm{H}_{1}$ and $\mathrm{H}_{2}$, pointing to higher conservative earnings for firms with greater foreign institutional ownerships, especially when information asymmetry is significant.

\subsection{Controlling for cost stickiness}

Banker et al. (2016) argue and provide evidence that the conservatism estimate in the Basu model is biased because the linear relation between earnings and returns can arise from the asymmetric response of changes in sales. In particular, they find that earnings are more sensitive to sales increases than sales decreases. To control for the confounding effects of cost stickiness, we re-estimate the model in Eq. (3) after incorporating $D S_{t}$, defined as a dummy variable that equals to one if changes in sales from year $t-1$ to year $t$ is negative, and zero otherwise; as well as $\Delta S_{t}$, defined as changes in sales from year $t-1$ to year $t$ that is scaled by the market value of equity at the beginning of the fiscal year. We also add an interaction term $D S_{t} * \Delta S_{t}$ along with their interactions with ownership types (i.e., $D S_{t}^{*} R F I O W N_{t-1}, \Delta S_{t}^{*} R F I O W N_{t-1}$, and $\left.D S_{t}^{*} \Delta S_{t}^{*} R F I O W N_{t-1}\right)$ and control variables. ${ }^{10}$ In

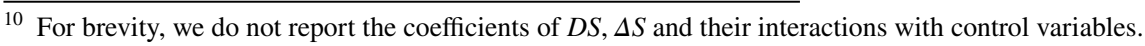


Table 7 The effect of foreign ownership on accounting conservatism measured by the Basu model controlling for cost stickness and using ownership decile ranks

\begin{tabular}{|c|c|c|c|c|c|}
\hline & \multirow[t]{2}{*}{ Exp. sign } & \multicolumn{2}{|c|}{ controlling for cost stickness } & \multicolumn{2}{|c|}{ using ownership decile ranks } \\
\hline & & (1) & (2) & (3) & (4) \\
\hline Ret $_{t}$ & & $\begin{array}{l}0.161 \\
(0.806)\end{array}$ & $\begin{array}{l}0.275 \\
(0.836)\end{array}$ & $\begin{array}{l}0.130 \\
(0.141)\end{array}$ & $\begin{array}{l}0.333 * * \\
(0.140)\end{array}$ \\
\hline $\mathrm{Neg}_{\mathrm{t}}$ & & $\begin{array}{l}-0.055 \\
(0.235)\end{array}$ & $\begin{array}{l}-0.064 \\
(0.227)\end{array}$ & $\begin{array}{l}-0.019 \\
(0.067)\end{array}$ & $\begin{array}{l}-0.046 \\
(0.066)\end{array}$ \\
\hline $\operatorname{Ret}_{t} * \mathrm{Neg}_{\mathrm{t}}$ & + & $\begin{array}{l}0.001 \\
(1.282)\end{array}$ & $\begin{array}{l}-0.123 \\
(1.294)\end{array}$ & $\begin{array}{l}0.089 \\
(0.178)\end{array}$ & $\begin{array}{l}-0.178 \\
(0.180)\end{array}$ \\
\hline$\Delta \mathrm{S}_{\mathrm{t}}$ & & $\begin{array}{l}0.185 \\
(0.304)\end{array}$ & $\begin{array}{l}0.051 \\
(0.273)\end{array}$ & & \\
\hline $\mathrm{DS}_{\mathrm{t}}$ & & $\begin{array}{l}-0.183 \\
(0.295)\end{array}$ & $\begin{array}{l}-0.224 \\
(0.273)\end{array}$ & & \\
\hline$\Delta \mathrm{S}_{\mathrm{t}} * \mathrm{DS}_{\mathrm{t}}$ & & $\begin{array}{l}-0.011 \\
(0.481)\end{array}$ & $\begin{array}{l}0.156 \\
(0.428)\end{array}$ & & $(0.180)$ \\
\hline RFOWN $_{t-1}$ & & & $\begin{array}{l}0.112 \\
(0.282)\end{array}$ & & $\begin{array}{l}-0.011 \\
(0.034)\end{array}$ \\
\hline Ret $_{\mathrm{t}} *$ RFIOWN $_{\mathrm{t}-1}$ & & & $\begin{array}{l}-1.527 * * \\
(0.610)\end{array}$ & & $\begin{array}{l}-0.235^{* * *} \\
(0.061)\end{array}$ \\
\hline $\mathrm{Neg}_{\mathrm{t}}$ *RFIOWN $\mathrm{t}_{\mathrm{t}-1}$ & & & $\begin{array}{l}0.038 \\
(0.672)\end{array}$ & & $\begin{array}{l}0.059 \\
(0.058)\end{array}$ \\
\hline Ret $_{t}^{*} \mathrm{Neg}_{\mathrm{t}} * \mathrm{RFIOWN}_{\mathrm{t}-1}$ & + & & $\begin{array}{l}1.518 * * * * \\
(0.274)\end{array}$ & & $\begin{array}{l}0.315^{* * *} \\
(0.101)\end{array}$ \\
\hline $\mathrm{Ret}_{\mathrm{t}}{ }^{*} \mathrm{Neg}_{\mathrm{t}} * \mathrm{RDIOWN}_{\mathrm{t}-1}$ & $?$ & $\begin{array}{l}-0.656 \\
(0.531)\end{array}$ & $\begin{array}{l}0.557 \\
(0.519)\end{array}$ & $\begin{array}{l}0.105 \\
(0.133)\end{array}$ & $\begin{array}{l}0.172 \\
(0.125)\end{array}$ \\
\hline Controls $_{t-1}$ & & Included & Included & Included & Included \\
\hline Ret $_{t}^{*}$ Controls $_{t-1}$ & & Included & Included & Included & Included \\
\hline $\mathrm{Neg}_{\mathrm{t}}{ }^{*}$ Controls $\mathrm{t}_{\mathrm{t}-1}$ & & Included & Included & Included & Included \\
\hline 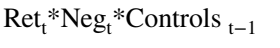 & & Included & Included & Included & Included \\
\hline$\Delta \mathrm{S}_{\mathrm{t}} *$ Controls & & Included & Included & Not included & Not included \\
\hline $\mathrm{DS}_{\mathrm{t}} *$ Controls & & Included & Included & Not included & Not included \\
\hline$\Delta \mathrm{S}_{\mathrm{t}}^{*} \mathrm{DS}_{\mathrm{t}} * \mathrm{RFOWN}_{\mathrm{t}-1}$ & & Not included & Included & Not included & Not included \\
\hline$\Delta \mathrm{S}_{\mathrm{t}} * \mathrm{DS}_{\mathrm{t}} * \mathrm{RDOWN}_{\mathrm{t}-1}$ & & Not included & Included & Not included & Not included \\
\hline $\mathrm{R}^{2}$ & & 0.177 & 0.191 & 0.141 & 0.154 \\
\hline \# observations & & 1618 & 1618 & 1618 & 1618 \\
\hline
\end{tabular}

This table reports results from the pooled OLS regressions, where the dependent variable is $N I$, defined as net income after extraordinary items, scaled by the beginning of the year market value of equity. $\Delta S_{t}$ represents the sales changes from year $\mathrm{t}-1$ to $\mathrm{t}$ scaled by the beginning of the market value of equity. $D S_{t}$ is a dummy variable equals to one if sales changes are negative and zero otherwise. All estimations include year dummies. Variable definitions are provided in Table 1. Standard errors are clustered at the firm and year level. $* * *, * *, *$ denote significance level at $1 \%, 5 \%$, and $10 \%$, respectively (two tailed). We do not remark the firm subscript $i$ for brevity. For Models 3 and 4, all variables, except Ret and Neg, are scaled decile ranks from 0 to 1

line with our earlier findings, the results in Table 7 confirm the positive relation between foreign institutional ownership and conservatism. 


\subsection{Decile rank of ownership}

As another robustness test, we follow prior studies (e.g., LaFond and Roychowdhury 2008; Ramalingegowda and $\mathrm{Yu}$ 2012) and use scaled decile ranks for all foreign ownership and other variables included in our estimations except NI, Ret, Neg, and LIT. We calculate the scaled decile ranks by first ranking the observations by year into ten groups from one to ten and then dividing the ranking by ten. As such, the rank variable ranges from zero to one. The reported results in Model (4) of Table 7 show that the estimated coefficient of $\operatorname{Ret}_{t} * \mathrm{Neg}_{t} * \mathrm{RFIOWN}_{t-1}$ is positive and significant at the $5 \%$ level, confirming our results that foreign institutional ownership is associated with higher conservatism.

\subsection{Causality tests}

The results above are consistent with the notion that higher ownership by foreign institutional investors is positively associated with conservatism. However, one may argue that local firms may reassure foreign investors and commit to more accounting conservatism to attract foreign investments (the 'reverse' causality explanation). It could also be the case since foreign institutions (particularly foreign corporations) are more likely to invest more in well-governed firms (Leuz et al. 2008). As a result, foreign institutional investors may be attracted to firms with more conservative reporting as a channel through which they can reduce their monitoring costs and information disadvantage. Moreover, an increase in foreign institutional residual ownership and conservatism may also arise simultaneously and driven by other unknown factors (the 'simultaneity' explanation) (Ramalingegowda and $\mathrm{Yu}$ 2012). To mitigate these concerns, we estimate lead-lag regressions by regressing accounting conservatism on the lagged, current, and lead values of residual institutional ownership. Following prior research (e.g., Ramalingegowda and Yu 2012), we add the current and lead residual ownership by foreign institutions to Eq. (3) as follows:

$$
\begin{aligned}
N_{i t}= & \beta_{0}+\beta_{1} \text { Neg }_{i t}+\beta_{2} \text { Ret }_{i t}+\beta_{3} \text { Neg }_{i t} * \text { Ret }_{i t}+\beta_{4} \text { RFIOWN }_{i t-1} \\
& +\beta_{5} \text { Neg }_{i t} * \text { RFIOWN }_{i t-1}+\beta_{6} \text { Ret }_{i t} * \text { RFIOWN }_{i t-1} \\
& +\beta_{7} \text { Neg }_{i t} * \operatorname{Ret}_{i t} * \text { RFIOWN }_{i t-1}+\beta_{8} \text { RFIOWN }_{i t} \\
& +\beta_{9} \text { Neg }_{i t} * \text { RFIOWN }_{i t}+\beta_{10} \text { Ret }_{i t} * \text { RFIOWN }_{i t} \\
& +\beta_{11} \text { Neg }_{i t} * \operatorname{Ret}_{i t} * \text { RFIOWN }_{i t}+\beta_{12} \text { RFIOWN }_{i t+1} \\
& +\beta_{13} \text { Neg }_{i t} * \text { RFIOWN }_{i t+1}+\beta_{14} t_{i t} * \text { RFIOWN }_{i t+1} \\
& +\beta_{15} \text { Neg }_{i t} * \operatorname{Ret}_{i t} * \text { RFIOWN }_{i t+1}+\beta_{16-20} \text { Controls }_{i t-1} \\
& +\beta_{21-25} \text { Neg }_{i t} * \text { Controls }_{i t-1}+\beta_{26-30} \text { Ret }_{i t} * \text { Controls }_{i t-1} \\
& +\beta_{31-35} \text { Neg }_{i t} * \text { Ret }_{i t} * \text { Controls }_{i t-1}+\varepsilon_{i t}
\end{aligned}
$$

If $\beta_{11}>0$ and significant, the reverse causality would be a concern and the simultaneity explanation would be consistent with a significant and positive $\beta_{15}$.

Table 8 presents the estimation results of this test. We find that accounting conservatism is positively associated with lagged residual ownership by foreign corporations. Specifically, the coefficient of $\mathrm{Neg}_{i t} * \operatorname{Ret}_{i t} * R F I O W N_{i t-1}$ is positive and statistically significant at the $1 \%$ level. This result is consistent with the conjuncture that higher ownership by foreign institutions leads to higher demand for conservatism. However, we find no relation between 
Table 8 The relationship between accounting conservatism and current, lagged, and lead foreign institutional ownership

\begin{tabular}{|c|c|c|c|c|c|}
\hline & Exp. sign & (1) & (2) & (3) & (4) \\
\hline $\operatorname{Ret}_{\mathrm{t}}$ & & $\begin{array}{l}0.209 \\
(0.912)\end{array}$ & $\begin{array}{l}0.120 \\
(0.892)\end{array}$ & $\begin{array}{l}0.233 \\
(0.947)\end{array}$ & $\begin{array}{l}0.098 \\
(0.914)\end{array}$ \\
\hline $\mathrm{Neg}_{\mathrm{t}}$ & & $\begin{array}{l}0.058 \\
(0.305)\end{array}$ & $\begin{array}{l}0.030 \\
(0.325)\end{array}$ & $\begin{array}{l}0.112 \\
(0.257)\end{array}$ & $\begin{array}{l}0.063 \\
(0.280)\end{array}$ \\
\hline $\operatorname{Ret}_{t} * \mathrm{Neg}_{\mathrm{t}}$ & + & $\begin{array}{l}0.366 \\
(1.193)\end{array}$ & $\begin{array}{l}0.436 \\
(1.264)\end{array}$ & $\begin{array}{l}0.421 \\
(1.219)\end{array}$ & $\begin{array}{l}0.516 \\
(1.208)\end{array}$ \\
\hline Ret $_{\mathrm{t}} * \mathrm{Neg}_{\mathrm{t}} * \mathrm{RFIOWN}_{\mathrm{t}-1}$ & + & $\begin{array}{l}1.375 * * * \\
(0.327)\end{array}$ & $\begin{array}{l}2.891 * \\
(1.228)\end{array}$ & $\begin{array}{l}1.907 * * * \\
(0.535)\end{array}$ & $\begin{array}{l}2.682 * * \\
(1.084)\end{array}$ \\
\hline $\operatorname{Ret}_{\mathrm{t}} * \mathrm{Neg}_{\mathrm{t}} * \mathrm{RFIOWN}_{\mathrm{t}}$ & $?$ & & $\begin{array}{l}-2.954^{*} \\
(1.492)\end{array}$ & & $\begin{array}{l}-3.700 \\
(2.417)\end{array}$ \\
\hline Ret $_{\mathrm{t}} * \mathrm{Neg}_{\mathrm{t}} * \mathrm{RFIOWN}_{\mathrm{t}+1}$ & $?$ & & & $\begin{array}{l}-1.305 \\
(1.726)\end{array}$ & $\begin{array}{l}1.110 \\
(2.636)\end{array}$ \\
\hline $\operatorname{Ret}_{\mathrm{t}} * \mathrm{Neg}_{\mathrm{t}} * \mathrm{RDIOWN}_{\mathrm{t}-1}$ & $?$ & $\begin{array}{l}0.694 \\
(0.612)\end{array}$ & $\begin{array}{l}0.571 \\
(0.505)\end{array}$ & $\begin{array}{l}0.647 \\
(0.634)\end{array}$ & $\begin{array}{l}0.373 \\
(0.664)\end{array}$ \\
\hline $\operatorname{Ret}_{\mathrm{t}}^{*} \mathrm{Neg}_{\mathrm{t}} * \mathrm{SIZE}_{\mathrm{t}-1}$ & - & $\begin{array}{l}0.001 \\
(0.072)\end{array}$ & $\begin{array}{l}-0.001 \\
(0.074)\end{array}$ & $\begin{array}{l}-0.002 \\
(0.073)\end{array}$ & $\begin{array}{l}-0.002 \\
(0.072)\end{array}$ \\
\hline $\operatorname{Ret}_{t} * \operatorname{Neg}_{t} * \operatorname{LEV}_{t-1}$ & + & $\begin{array}{l}-0.511 \\
(0.604)\end{array}$ & $\begin{array}{l}-0.542 \\
(0.617)\end{array}$ & $\begin{array}{l}-0.563 \\
(0.616)\end{array}$ & $\begin{array}{l}-0.579 \\
(0.629)\end{array}$ \\
\hline $\operatorname{Ret}_{\mathrm{t}} * \mathrm{Neg}_{\mathrm{t}} * \mathrm{MB}_{\mathrm{t}-1}$ & - & $\begin{array}{l}0.008 \\
(0.037)\end{array}$ & $\begin{array}{l}0.013 \\
(0.033)\end{array}$ & $\begin{array}{l}0.014 \\
(0.038)\end{array}$ & $\begin{array}{l}0.007 \\
(0.035)\end{array}$ \\
\hline $\operatorname{Ret}_{\mathrm{t}} * \mathrm{Neg}_{\mathrm{t}} * \mathrm{RISK}_{\mathrm{t}-1}$ & + & $\begin{array}{l}-9.307 \\
(7.605)\end{array}$ & $\begin{array}{l}-10.484 \\
(7.319)\end{array}$ & $\begin{array}{l}-10.339 \\
(7.658)\end{array}$ & $\begin{array}{l}-11.600 \\
(7.435)\end{array}$ \\
\hline $\operatorname{Ret}_{\mathrm{t}}^{*} \mathrm{Neg}_{\mathrm{t}} * \mathrm{AGE}_{\mathrm{t}-1}$ & - & $\begin{array}{l}-0.016 \\
(0.142)\end{array}$ & $\begin{array}{l}-0.022 \\
(0.130)\end{array}$ & $\begin{array}{l}-0.002 \\
(0.151)\end{array}$ & $\begin{array}{l}-0.026 \\
(0.144)\end{array}$ \\
\hline $\operatorname{Ret}_{t}^{*} \mathrm{Neg}_{\mathrm{t}} * \mathrm{LIT}_{\mathrm{t}-1}$ & + & $\begin{array}{l}-0.114 \\
(0.169)\end{array}$ & $\begin{array}{l}-0.080 \\
(0.156)\end{array}$ & $\begin{array}{l}-0.145 \\
(0.154)\end{array}$ & $\begin{array}{l}-0.103 \\
(0.143)\end{array}$ \\
\hline Controls $_{t-1}$ & & Included & Included & Included & Included \\
\hline Ret $_{\mathrm{t}} *$ Controls $_{\mathrm{t}-1}$ & & Included & Included & Included & Included \\
\hline $\mathrm{Neg}_{\mathrm{t}} *$ Controls $_{\mathrm{t}-1}$ & & Included & Included & Included & Included \\
\hline RFIOWN (current, lead, and lag) & & Included & Included & Included & Included \\
\hline Ret $_{\mathrm{t}}^{*}$ RFIOWN (current, lead, and lag) & & Included & Included & Included & Included \\
\hline $\mathrm{Neg}_{\mathrm{t}}{ }^{*}$ RFIOWN (current, lead, and lag) & & Included & Included & Included & Included \\
\hline $\mathrm{R}^{2}$ & & 0.135 & 0.143 & 0.143 & 0.154 \\
\hline \# observations & & 1428 & 1428 & 1428 & 1428 \\
\hline
\end{tabular}

This table reports results from the pooled OLS regressions, where the dependent variable is $N I$, defined as net income after extraordinary items, scaled by the beginning of the year market value of equity. All estimations include year dummies. Variable definitions are provided in Table 1. Cluster-adjusted robust standard errors are in parenthesis. Standard errors are clustered at the firm and year level. ***, **, * denote significance level at $1 \%, 5 \%$, and $10 \%$, respectively (two-tailed). We do not remark the firm subscript $i$ for brevity

the current or lead residual ownership by foreign institutions and conservatism, suggesting that the reverse causality or the simultaneity explanations are not major concerns in this study. In summary, the results of this test suggest that our results above are not driven by 
the causality or simultaneity concerns and that higher foreign institutional ownership leads to more accounting conservatism. ${ }^{11}$

\section{Conclusion}

This study investigates whether foreign institutional investors demand more conservative reporting when they hold equity shareholdings in domestic firms. We argue that they desire more conservatism as conservative reporting is expected to play an important governance role in reducing the informational disadvantages faced by foreign investors.

Using a unique dataset for a sample of publicly listed firms in Borsa Istanbul, our univariate analysis and multivariate regression results show that higher foreign institutional ownership exerts a positive impact on accounting conservatism. This possibly suggests that foreign investors demand more conservative reporting practices. However, we also find that foreign corporate investors are the primary driver of the demand for conservative reporting. Moreover, the positive relationship between conservatism and foreign institutional ownership is more pronounced among firms prone to greater information asymmetry and growth opportunities. Importantly, our results indicate that the demand for accounting conservatism is stronger by foreign than domestic investors. This finding may arise from the alternative means which domestic investors employ to mitigate the costs of the potential agency. Our results are robust when we use an alternative measure of accounting conservatism and employ different empirical specifications. Finally, the results remain qualitatively similar when we also control for potential reverse causality and simultaneity problems.

Our study extends prior research by providing evidence for the role of foreign institutional investors in shaping corporate reporting practices. Moreover, we provide direct evidence from an emerging market where the demand for conservatism is likely to be driven by lower levels of transparency, greater informational problems, weaker governance practices, and greater agency costs. Although the International Accounting Standards Board (IASB) and Financial Accounting Standards Board (FASB) remove accounting conservatism from the conceptual frameworks of financial reporting, our results run against the view that conservatism is not an essential feature of accounting information. The results provide support for the relevance of accounting conservatism to investors who are informationally disadvantaged. The analysis, therefore, contributes to the ongoing debate about the benefits of accounting conservatism in equity markets. ${ }^{12}$ In this respect, the findings of this study can be of interest to regulators and policymakers.

Our results, however, should be interpreted with the following caveats in mind. First, a key concern regarding the explanation of our results relates to the ability of accounting conservatism proxies to capture conservative reporting behavior adequately. Although we employ alternative measures of accounting conservatism, we cannot rule out the possibility that the potential measurement errors associated with these proxies can drive the results. Second, while we attempt to mitigate the potential consequences, reverse causality and simultaneity can still be of empirical concerns. Third, our study does not identify any

\footnotetext{
11 Our results are qualitatively similar when we perform firm-fixed effects estimation and also drop domestic ownership from our empirical specification.

12 The debates with and against the removal of accounting conservatism from the conceptual framework or its benefits from value relevance and contracting views are beyond the scope of this paper and we refer the reader to other studies (e.g., Mora and Walker 2015) for more discussion.
} 
other mechanisms that foreign investors can use alternatively or jointly with conservatism to control for the adverse consequences of capital market imperfections. This awaits future research.

Open Access This article is distributed under the terms of the Creative Commons Attribution 4.0 International License (http://creativecommons.org/licenses/by/4.0/), which permits unrestricted use, distribution, and reproduction in any medium, provided you give appropriate credit to the original author(s) and the source, provide a link to the Creative Commons license, and indicate if changes were made.

\section{References}

Aggarwal R, Erel I, Ferreira M, Matos P (2011) Does governance travel around the world? Evidence from institutional investors. J Financ Econ 100:154-181

Ahmed AS, Duellman S (2007) Accounting conservatism and board of director characteristics: an empirical analysis. J Account Econ 43:411-437

Ball R (2001) Infrastructure requirements for an economically efficient system of public financial reporting and disclosure. Brook Whart Pap Financ Serv 2001:127-169

Ball R, Shivakumar L (2005) Earnings quality in UK private firms: cooperative loss recognition timeliness. J Account Econ 39:83-128

Ball R, Kothari SP, Nikolaev VV (2013) Econometrics of the Basu asymmetric timeliness coefficient and accounting conservatism. J Account Res 51:1071-1097

Banker R, Basu S, Byzalov D, Chen J (2016) The confounding effect of cost stickiness on conservatism estimates. J Account Econ 61:203-220

Basu S (1997) The conservatism principle and the asymmetric timeliness of earnings. J Account Econ 24:3-37

Basu S, Huang AY-F, Mitsudome T, Weintrop J (2005) Timeliness and conservatism of Taiwanese earnings. Asia Pac J Account Econ 12:113-134

Beekes W, Pope P, Young S (2004) The link between earnings timeliness, earnings conservatism and board composition: evidence from the UK. Corp Gov Int Rev 12:47-59

Bena J, Ferreira MA, Matos P, Pires P (2017) Are foreign investors locusts? The long-term effects of foreign institutional ownership. J Financ Econ 126:122-146

Beneish MD, Yohn TL (2008) Information friction and investor home bias: a perspective on the effect of global IFRS adoption on the extent of equity home bias. J Account Public Policy 27:433-443

Beuselinck C, Blanco B, García Lara JM (2017) The role of foreign shareholders in disciplining financial reporting. J Bus Financ Account 44:558-592

Bushman R, Chen Q, Engel E, Smith A (2004) Financial accounting information, organizational complexity and corporate governance systems. J Account Econ 37:167-201

Chen XC, Yur-Austin J (2007) Re-measuring agency costs: the effectiveness of blockholders. Q Rev Econ Financ 47:588-601

Chen X, Harford J, Li K (2007) Monitoring: which institutions matter? J Financ Econ 86:279-305

Chen S, Chen X, Cheng Q (2014) Conservatism and equity ownership of the founding family. Eur Account Rev 23:403-430

Cheng CA, Huang HH, Li Y (2015) Hedge fund intervention and accounting conservatism. Contemp Account Res 32:392-421

Ciftci I, Tatoglu E, Wood G, Demirbag M, Zaim S (2019) Corporate governance and firm performance in emerging markets: evidence from Turkey. Int Bus Rev 28:90-103

Desender KA, Aguilera RV, Lópezpuertas-Lamy M, Crespi R (2016) A clash of governance logics: foreign ownership and board monitoring. Strat Manag J 37:349-369

Dietrich JR, Muller KA, Riedl EJ (2007) Asymmetric timeliness tests of accounting conservatism. Rev of Account Stud 12:95-124

Douma S, George R, Kabir R (2006) Foreign and domestic ownership, business groups, and firm performance: evidence from a large emerging market. Strat Manag J 27:637-657

Elitas C, Uc M (2009) The change on the foundations of the Turkish accounting system and the future perspective. Crit Perspect on Account 20:674-679

Eng LL, Lin YC (2012) Accounting quality, earnings management and cross-listings: evidence from China. Rev Pac Basin Financ Mark Policy 15(2):125-150 
Ettredge M, Huang Y, Zhang W (2012) Earnings restatements and differential timeliness of accounting conservatism. J Account Econ 53:489-503

Fan JP, Wong TJ (2002) Corporate ownership structure and the informativeness of accounting earnings in East Asia. J Account Econ 33:401-425

Ferreira MA, Matos P (2008) The colors of investors' money: the role of institutional investors around the world. J Financ Econ 88:499-533

Ferreira MA, Matos P, Pereira JP, Pires P (2017) Do locals know better? A comparison of the performance of local and foreign institutional investors. J Bank Financ 82:151-164

García Lara JM, Osma BG, Neophytou E (2009) Earnings quality in ex-post failed firms. Account Bus Res 39:119-138

Gillan S, Starks LT (2003) Corporate governance, corporate ownership, and the role of institutional investors: A global perspective. Weinberg Center for Corporate Governance Working Paper No. 2003-01. Available at SSRN: https://ssrn.com/abstract $=439500$

Giner B, Ress W (2001) On the asymmetric recognition of good and bad news in France, Germany and the United Kingdom. J Financ Account 28:1285-1331

Givoly D, Hayn CK, Natarajan A (2007) Measuring reporting conservatism. Account Rev 82:65-106

Gow ID, Ormazabal G, Taylor DJ (2010) Correcting for cross-sectional and time-series dependence in accounting research. Account Rev 85:483-512

Grinblatt M, Keloharju M (2000) The investment behavior and performance of various investor types: a study of Finland's unique data set. J Financ Econ 55:43-67

He X, Rui O, Zheng L, Zhu H (2014) Foreign ownership and auditor choice. J Account Public Policy 33:401-418

Himmelberg CP, Hubbard RG, Palia D (1999) Understanding the determinants of managerial ownership and the link between ownership and performance. J Financ Econ 53:353-384

Hu C, Jiang W (2019) Managerial risk incentives and accounting conservatism. Rev Quant Finan Account $52: 781-813$

Jayaraman S (2012) The effect of enforcement on timely loss recognition: evidence from insider trading laws. J Account Econ 53:77-97

Khan M, Watts RL (2009) Estimation and empirical properties of a firm-year measure of accounting conservatism. J Account Econ 48:132-150

Kim JB, Zhang L (2016) Accounting conservatism and stock price crash risk: firm-level evidence. Contemp Account Res 33:412-441

Kim Y, Li S, Pan C, Zuo L (2013) The role of accounting conservatism in the equity market: evidence from seasoned equity offerings. Account Rev 88:1327-1356

Kim I, Miller S, Wan H, Wang B (2016) Drivers behind the monitoring effectiveness of global institutional investors: evidence from earnings management. J Corp Financ 40:24-46

Lafond R, Roychowdhury S (2008) Managerial ownership and accounting conservatism. J Account Res 46:101-135

LaFond R, Watts RL (2008) The information role of conservatism. Account Rev 83:447-478

Lai L, Tam H (2017) Corporate governance, ownership structure and managing earnings to meet critical thresholds among Chinese listed firms. Rev Quant Finan Acc 48:789-818

Lel U (2017) The role of foreign institutional investors in restraining earnings management activities across countries. https://ssrn.com/abstract=2223651. Accessed 27 Dec 2018

Leuz C, Lins KV, Warnock FE (2008) Do foreigners invest less in poorly governed firms? Rev Financ Stud 22:3245-3285

Liang JW, Lin MF, Chin CL (2012) Does foreign institutional ownership motivate firms in an emerging market to increase voluntary disclosure? Evidence from Taiwan. Rev Quant Finan Acc 39:55-76

Lin L (2016) Institutional ownership composition and accounting conservatism. Rev Quant Finan Acc 46:359-385

Lin L, Manowan P (2012) Institutional ownership composition and earnings management. Rev Pac Basin Financ Mark Policy 15:1-22

Mora A, Walker M (2015) The implications of research on accounting conservatism for accounting standard setting. Account Bus Res 45:620-650

Petersen MA (2009) Estimating standard errors in finance panel data sets: comparing approaches. Rev Financ Stud 22:435-480

Ramalingegowda S, Yu Y (2012) Institutional ownership and conservatism. J Account Econ 53:98-114

Ryan SG (2006) Identifying conditional conservatism. Eur Account Rev 15:511-525

Sakaki H, Jackson D, Jory S (2017) Institutional ownership stability and real earnings management. Rev Quant Finan Acc 49:227-244 
Shroff N, Sun AX, White HD, Zhang W (2013) Voluntary disclosure and information asymmetry: evidence from the 2005 securities offering reform. J Account Res 51:1299-1345

Simga-Mugan C (1995) Accounting in Turkey. Eur Account Rev 4:351-371

Smith CW, Watts RL (1992) The investment opportunity set and corporate financing, dividend, and compensation policies. J Financ Econ 32:263-292

Wang D (2006) Founding family ownership and earnings quality. J Account Res 44:619-656

Watts RL (2003) Conservatism in accounting part I: explanations and implications. Account Horiz 17:207-221

Watts RL, Zimmerman JL (1990) Positive accounting theory: a ten year perspective. Account Rev 65:131-156

World Bank (2007) Turkey-Report on the Observance of Standards and Codes (ROSC): accounting and auditing. The report is available at http://documents.worldbank.org/curated/en/974031468172442987/ pdf/662380ROSC00PU04B0Turkey0March02007.pdf. Accessed 30 Dec 2018

Publisher's Note Springer Nature remains neutral with regard to jurisdictional claims in published maps and institutional affiliations. 